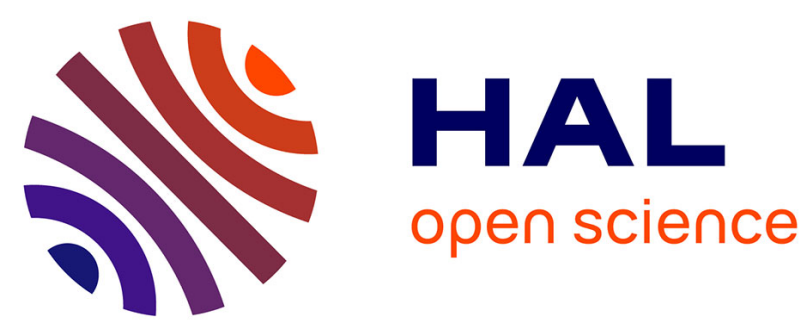

\title{
Endocrine disrupting compounds in gaseous and particulate outdoor air phases according to environmental factors
}

Marie-Jeanne Teil, Elodie Moreau-Guigon, Martine Blanchard, Fabrice Alliot, Johnny Gasperi, Mathieu Cladière, Corinne Mandin, Sophie Moukhtar, Marc Chevreuil

\section{To cite this version:}

Marie-Jeanne Teil, Elodie Moreau-Guigon, Martine Blanchard, Fabrice Alliot, Johnny Gasperi, et al.. Endocrine disrupting compounds in gaseous and particulate outdoor air phases according to environmental factors. Chemosphere, 2016, 146, pp.94-104. 10.1016/j.chemosphere.2015.12.015 . hal-01250062

\section{HAL Id: hal-01250062 \\ https://hal-enpc.archives-ouvertes.fr/hal-01250062}

Submitted on 6 Jan 2016

HAL is a multi-disciplinary open access archive for the deposit and dissemination of scientific research documents, whether they are published or not. The documents may come from teaching and research institutions in France or abroad, or from public or private research centers.
L'archive ouverte pluridisciplinaire HAL, est destinée au dépôt et à la diffusion de documents scientifiques de niveau recherche, publiés ou non, émanant des établissements d'enseignement et de recherche français ou étrangers, des laboratoires publics ou privés. 


\section{Endocrine disrupting compounds in gaseous and particulate outdoor air}

2

3

4

5

6

7

8

9

10

11

12

13

14

15

16

17

18

19

20

\section{phases according to environmental factors}

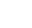

Marie-Jeanne Teil ${ }^{1}$, Elodie Moreau-Guigon ${ }^{1}$, Martine Blanchard $^{1}$, Fabrice Alliot $^{1}$,

Johnny Gasperi ${ }^{2}$, Mathieu Cladière ${ }^{2},{\text { Corinne } \text { Mandin }^{3}, \text { Sophie Moukhtar }}^{4}$, Marc Chevreuil $^{1}$

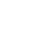

${ }^{1}$ EPHE, UMR 7619 METIS (UPMC - Univ Paris 06/CNRS/EPHE), UPMC 4place Jussieu, 75005, Paris, France.

2. Université Paris-Est, LEESU, UMR MA 102 - AgroParisTech, 61 avenue du Général de Gaulle, 94010 Créteil Cedex, France.

${ }^{3 .}$ Université Paris-Est, Centre Scientifique et Technique du Bâtiment (CSTB), 77447 Marne-La-Vallée, France.

4. Airparif, Association de Surveillance de la qualité de l'air en Île-de-France, 7 rue Crillon, 75004 Paris, France.

(*) Corresponding author: marie-jeanne.teil@upmc.fr

Keywords: endocrine disrupting compounds, semi-volatile organic compounds, outdoor air, gaseous phase, particulate phase 


\section{Abstract}

This study investigated, for the first time in France, the spatial and temporal patterns of 55 endocrine disrupting chemicals (EDCs) in ambient air at three sites (urban, suburban and forest) under two climatic periods (warm/cold) for 2 successive years. All EDCs, except tetrabromobisphenol A (TBBPA), were encountered with various frequencies of up to $100 \%$. Phthalate diesters (PAEs) were the most abundant chemicals with total concentrations as the sum of compounds, ranging from 10 to $100 \mathrm{ng} \mathrm{m}^{-3}$ of total air, followed by alkylphenols (APs) and polycyclic aromatic hydrocarbons (PAHs), which were both approximately $1 \mathrm{ng} \mathrm{m}^{-3}$. Polychlorinated biphenyl (PCBs) and bisphenol A (BPA) concentrations were notably lower (approximately $0.1 \mathrm{ng} \mathrm{m}^{-3}$ ). Air concentrations, depending on the considered compounds, were from 1.2 to 2 times higher in the urban than the suburban area and from 2 to 5 times higher in the urban than the forest site. PAH emissions were higher in the cold period, due to combustion processes. This finding is contrary to the other EDCs that are more abundant in the summer and governed by volatilisation. Most of the EDCs were largely distributed in the gaseous phase (> 80\% in the summer). The octanol/air partition coefficient $\left(\mathrm{K}_{\mathrm{OA}}\right)$ and vapour pressure $(\mathrm{Vp})$ were relevant parameters for predicting EDC partitioning and direct relationships $(\mathrm{p}<0.001)$ were observed i) between $\log \mathrm{K}$ particle/gas partitioning (log $\mathrm{Kp}$ ) and $\log \mathrm{K}_{\mathrm{OA}}$ and ii) between EDC ratios in the gaseous phase and log vapor pressure $(\log \mathrm{Vp})$. 
41 EDCs in the Paris area were similar to Western countries except PAHs and PBDEs

42 PCBs and PAEs showed an urban signature

43 AP, PAH and PBDE sources were more distributed along a urban-suburban transect

44 EDCs prevailed in gaseous phase whatever the season except DEHP and heavy PAHs 45 


\section{Introduction}

The continuous release of a number of endocrine disrupting chemicals (EDCs), such as bisphenol A (BPA), tetrabromobisphenol A (TBBPA), phthalate diesters (PAEs), alkylphenols (APs), polychlorinated biphenyls (PCBs), polybrominated diphenyl ethers (PBDEs) and polycyclic aromatic hydrocarbons (PAHs), to the environment generates new concerns regarding human exposure to low doses of toxic mixtures and possible subsequent effects on health (Benachour et al., 2007; Woodruff, 2011).

The emission sources of these chemicals have greatly increased and diversified over the past decades (EEA, 2013); and therefore, they have appeared as major air contaminants, particularly because of their semi-volatile properties (Rudel and Perovich, 2009). Thus, PAEs, APs, PCBs and PBDEs that are not chemically bound to matrices might become easily dispersed by volatilisation (Palm et al., 2002; Fujii et al., 2003; Liang and Xu, 2014).

PAEs can be emitted into the atmosphere from commonly used products, plastics, detergents, building materials or furniture (Wormuth et al., 2006). To date, despite a wide use of BPA in polycarbonate and epoxy resin production, emission sources and subsequent impacts upon ambient air quality remain poorly documented (Huang et al., 2012).

APs are by-products of alkylphenol ethoxylates largely used in household detergents. The European directive 2003/53/EC that came into force in January 2005 restrained the use of products containing more than $0.1 \%$ nonylphenols (NP) or nonylphenol ethoxylates. However, alkylphenol ethoxylates are still applied as dispersing agents in pulp and paper production, emulsifying agents in latex paints, glue and pesticides or in the preparation of antioxidants, curing agents and heat stabilisers for polymer resins and may be emitted to the environment from building materials (Saito et al., 2004).

PBDEs, a major class of flame retardants used in a number of manufactured goods to reduce their flammability, were composed of three major commercial formulations: penta- 
BDE, octa-BDE and deca-BDE (de Wit et al., 2010). Since 2003, penta- and octa-BDE were banned of use in all applications for the European Union market (Directive2003/11/EC) DecaBDE was registered under the "Registration, Evaluation, Authorisation and Restriction of Chemicals" (REACH) in 2010 and thus its uses have been restricted to applications such as automotive equipment, textiles and construction and suppressed for electric and electronic equipment (Deca-BDE, 2012). Tetrabromobisphenol A (TBBPA) is used as a reactive or additive flame retardant in polymers such as ABS, epoxy and polycarbonate resins, polystyrene, phenolic resins or adhesives (Who, 1995).

Chlorinated compounds such as hexachlorobenzene (HCB) and PCBs have been classified as persistent organic pollutants in the 1998 Aarhus Protocol (Aarhus, 24 June 1998), in the framework of the Geneva Convention on long-range transboundary air pollution. Dispersive uses of PCBs were banned in France by the Decree of 8 July 1975 and their uses were restricted to in-service equipment by a second decree in February 1986. Finally, in February 2003, a decree on the elimination of all equipment containing PCBs before the end of 2010 has been published. An unknown stock of PCBs is within now buried landfills and other waste-handling facilities as well as diffuse sources such as electrical wiring and paints (Diamond et al, 2010). Most recently, new "non-aroclor" PCBs were detected as byproduct of diarylide yellow (Rodenburg et al., 2010) and other pigment production (Anezaki et al., 2015).

Although HCB production has ceased since 1993, this compound is still being generated inadvertently as a by-product and/or an impurity in several chemical processes (Bonnomet et al., 2011) and pentachlorobenzene (PeCB) occurs as a by-product of $\mathrm{HCB}$ degradation (Brignon, 2005).

PAHs are continuously produced by combustion processes, mainly from domestic heating and automobile traffic (Katsoyiannis et al., 2011; Tobiszewski and Namieśnik, 2012). Despite 
PAHs are not considered as POPs, they were included to the Aarhus protocol. The objective was to reduce their emissions from stationary sources below their levels in 1990. For the emission inventories, the four indicator compounds shall be used: benzo(a)pyrene, benzo(b)fluoranthene, benzo(k)fluoranthene, and indeno(1,2,3-cd)pyrene.

Consequently, EDCs might undergo local or long range transport and their residence time in the air depends on climatic conditions and pollutant partitioning between the gaseous and particulate phases (Wania, 2003).

This study investigated for the first time in France, the atmospheric fate of a wide variety of EDCs ( $\mathrm{n}=55)$ including PCBs, PBDEs, PAHs, APs, PAEs, HCB, PeCB, BPA and TBBPA, and considering both their gaseous and particulate phases. The target compounds were selected according to suspicion of endocrine disrupting properties, to their classification as POPs and semi-volatile organic compounds and to their environmental occurrence. The concentration levels for the different EDC families were first considered, in order to highlight the general trends of EDC distribution in France and to compare with the contamination in other countries. As EDCs result from various sources, the spatial variations between three sites located respectively in urban, suburban and forest areas were studied. In addition, temporal variations between two contrasted seasons with and without domestic heating and between two successive years were investigated. Next, the particle/gas partitioning was examined on the basis of compound molecular properties. Last, relationships between outdoor temperature, suspended particles < $10 \mu \mathrm{m}$ (PM10) and EDC air concentrations were explored at the most polluted site.

\section{Material and Methods}

\subsection{Sampling schedule}

The three sampling sites belonged to the local air monitoring network of the Ile-de- 
France district (Airparif) (Fig. Supplementary Material - SM 1).

Two sampling campaigns were carried out at the following 3 sampling sites in the Paris region: urban centre residential (population density: 20000 inhab $\mathrm{km}^{-2}$ ) - Paris $13^{\text {th }}(75013)$, suburban residential area (population density 4400 inhab $\mathrm{km}^{-2}$ ) - Lognes (77185 - Seine et Marne) and forest area (population density: 87 inhab $\mathrm{km}^{-2}$ ) - Fontainebleau (77186 - Seine et Marne). The prevailing wind direction was W/NW. Because of logistical constraints, only two sites per year were simultaneously sampled: first, Paris/Fontainebleau (distance between the 2 sites, $56.5 \mathrm{~km}$ ) and then Paris/Lognes (distance $20 \mathrm{~km}$ ).

The first campaign was carried out for two periods: summer 2010 and winter 2010/2011 at the urban (Paris $13^{\text {th }}$ ) and the forest (Fontainebleau) sites. The second campaign was carried out in summer 2011 and winter 2011/2012 and was performed at the urban and the suburban sites i.e., Paris and Lognes.

Each sampling period consisted of three successive and individual samples over $14 \mathrm{~d}$, accounting for 42 sampling days. Sampling conditions are presented in Table SM.1. Air sample volumes ranged from 276 to $555 \mathrm{~m}^{3}$.

\subsection{Sample collection and treatment}

The particulate phases were sampled onto quartz fibre filters (porosity $0.3 \mu \mathrm{m}$ supplied by Whatman) and gaseous phases onto XAD-2 resin (20-60 mesh). The resin from SigmaAldrich (Saint-Quentin Fallavier, France) was cleaned and dried under vacuum, and $75 \mathrm{~g}$ were introduced into two brass cartridges $(2 \mathrm{~cm}$ diameter; $20 \mathrm{~cm}$ length). The filters were put on open aluminium filter holders (Ecomesure, Janvry, France) and used in total suspended particle mode (Granier and Chevreuil, 1997). The sampler (filter and resin) was connected to a sampling pump (Busch, model SV1005GP) with a paddle dryer combined with a timer and an air flow meter (Hivolin, Germany). To secure the trapping of all EDCs, air speed through 
the system was $<170 \mathrm{~cm} \mathrm{~s}^{-1}$ as stated in the IEPA method (IEPA/APC/85-003, 1985). The air flow in the sampler remained constant, from 1.2 to $1.8 \mathrm{~m}^{3} \mathrm{~h}^{-1}$ (Table SM.1). The outdoor temperatures and the concentrations of particulate matter $<10 \mu \mathrm{m}$ in diameter (PM10) were supplied by Airparif (Table SM.1).

The entire experimental procedures (sampling + clean-up + fractionation) and validations for sampling, extraction and analytical methods (Tables SM.2 to SM.7) were previously described (Alliot et al., 2014). The XAD-2 resins and filters were extracted separately. An aliquot of each extract was kept for AP analyses using a method previously developed (Cladière et al., 2013). Laboratory blanks were run for each series with clean XAD-2 resins and clean filters (matrix blank). They were subtracted from sample values. Internal standards were added to samples prior to extraction and compounds were quantified by internal calibration. Syringe standards were added to vials prior to analyses to determine internal standard recoveries.

\subsection{Presentation of the results}

The results for each site are presented as the mean \pm standard deviation $(n=6)$ and as the median. Mean gaseous and particulate phase concentrations $(n=3)$ are calculated for each season. PAEs are expressed both as individual compounds and as the sum of 7 PAEs ( $\left.\sum 7 \mathrm{PAEs}\right)$. APs are expressed as the sum of octylphenol and 4-nonylphenols $\left(\sum \mathrm{OP}+\mathrm{NP}\right)$. PCBs are expressed as $\sum \mathrm{PCBi}$ (the sum of $7 \mathrm{PCB}$ indicators for the monitoring of PCBs in Europe: CB28, 52, 101, 118, 138, 153 and 180), $\sum$ PCB-DL (the sum of CB77, 81, 126, 169 for the non-ortho polychlorinated dibenzo-p-dioxins-like PCBs and CB105, 114, 118, 123, $156,157,167,189$ for the mono-ortho polychlorinated dibenzo-p-dioxins-like PCBs) and $\sum 19$ PCBs. PBDEs are expressed as individual compounds and as $\sum 8$ PBDEs (the sum of BDE28, 47, 99, 100, 153, 154, 183 and 209). PAHs are expressed as the individual 
compounds of the French regulation (Decree of 02/02/1998) for atmospheric emissions (ATEP9870017A, 1998): fluorene (FLU), phenanthrene (PHE) and benzo(a)pyrene (BaP), $\sum 8$ PAHs (the sum of fluoranthene - FTH, benzo(a)anthracene - BaA, benzo(b)fluoranthene $\mathrm{BbF}$, benzo(k)fluoranthene - $\mathrm{BkF}, \mathrm{BaP}, \quad$ indeno(1,2,3-cd)pyrene $\quad-\quad$ IcdP, dibenzo(a,h)anthracene - DahA, and benzo(g,h,i)perylene - BghiP) and as $\sum 15$ PAHs (Table SM.6).

The EDC groups were represented by compounds with low and high molecular weights to give a comprehensive view of their behaviour. Relationships between i) compounds as \% in the gaseous phase and $\log$ of their vapour pressure $\left(\log \mathrm{Vp}, \mathrm{Pa}\right.$ at $\left.25^{\circ} \mathrm{C}\right)$ and ii) between $\log \mathrm{K}$ particle/gas partitioning $(\log \mathrm{Kp})$ and $\log$ octanol/air partition coefficient $\left(\log \mathrm{K}_{\mathrm{OA}}\right.$ ) were explored.

Statistical analyses of spatial and temporal variations were performed with the nonparametric test of Mann-Whitney, and correlation significances were expressed by Spearman's $r$ coefficient at $\alpha=0.05$. A principal component analysis - PCA (XLSTAT PRO software; Copyright holder CC-BY-SA-3.0, Addinsoft, Paris, France) was used for the Paris site with a diagram sorting out the main trends of the different EDC concentrations for the two campaigns. When the measured concentration was < the limit of quantification (LOQ), the LOQ value divided by 2 was used for the mean calculation and for the PCA analysis (Decree, July 08 2010).

\section{Results and Discussion}

\subsection{General trends}

All of the targeted EDCs except for TBBPA were quantified in the ambient air at the urban, suburban and forest sites (Table 1 and Table 2). The patterns for each site and season are shown in Fig. 1. In decreasing order, the overall concentration ( $\sum$ of gaseous and 
particulate phases) trends were similar and are as follows, PAEs $>$ APs $\geq$ PAHs $>$ PCBs $>$ $\mathrm{BPA}>\mathrm{HCB}>\mathrm{PeCB}>$ PBDEs.

PAEs were encountered in all air samples, and their concentrations ranged from 6.8 to $165 \mathrm{ng} \mathrm{m}^{-3}$ as the $\sum$ 7PAEs. The main compound was DEHP (from 0.1 to $156 \mathrm{ng} \mathrm{m}^{-3}$ ) followed by DiBP (from 3.2 to $30 \mathrm{ng} \mathrm{m}^{-3}$ ) and DnBP (from 0.1 to $11 \mathrm{ng} \mathrm{m}^{-3}$ ). These compounds were detected at a frequency of $100 \%$. DEHP concentrations are in accordance with those previously measured in Paris (France) (Teil et al., 2006) and in the Netherlands (Peijnenburg and Struijs, 2006).

APs and PAHs were the second most abundant EDC group (Fig. 1). OP and NP were always detected and their concentrations ranged respectively, from 0.034 to $0.657 \mathrm{ng} \mathrm{m}^{-3}$ and from 0.216 to $2.08 \mathrm{ng} \mathrm{m}^{-3}$. NP represented the major constituent of the total APs ( 72 to $88 \%$ ). This is consistent with literature data i.e., NP concentrations from 0.15 to $1 \mathrm{ng} \mathrm{m}^{-3}$ in the gas phase and from 0.0017 to $0.117 \mathrm{ng} \mathrm{m}^{-3}$ in the particulate phase of ambient air in NE-Bavaria, Germany ((Berkner et al., 2004).

The $\sum 8$ PAHs were quantified in all samples with concentrations ranging from 0.215 to $1.93 \mathrm{ng} \mathrm{m}^{-3}$. PAH concentrations in decreasing order were PHE > FLU > FTH (Table SM.8). A similar sequence was observed at a suburban site located nearby in Paris in 2010 (MotelayMassei et al., 2003). Literature data are scarce for periods similar to this study. Our concentrations remained lower than those of high volume air sampling (5.3 to $71.6 \mathrm{ng} \mathrm{m}^{-3}$ as $\sum 14$ PAHs) at four locations in the Chesapeake bay (USA) in 1994 (Gustafson and Dickhut, 1997)'. In Bursa (Turkey), for the period 2008-2009, residential and suburban sites showed average concentrations of respectively, 77 and $30 \mathrm{ng} \mathrm{m}^{-3}$ as $\sum 12 \mathrm{PAHs}$, PHE and FLU being the predominant compounds (Birgul and Tasdemir, 2015).

PCBi were present in all samples with the concentration of the $\sum$ PCBi ranging from 0.024 to $0.327 \mathrm{ng} \mathrm{m}^{-3}$ (Table 1 and Table 2). These values are consistent with those found in 
Northern France in 2002 (Blanchard et al., 2006) but were much lower than those of the Paris area in the 1980s (Granier and Chevreuil, 1997). Thus, after a significant drop linked to the French regulation since the 1970 s, a steady state was observed due to the persistence of diffuse sources. Mean concentrations from high volume sampling in urban/industrial location in Barcelona (Spain), in 2005, were similar to ours: $0.17 \mathrm{ng} \mathrm{m}^{-3}$ (Mari et al., 2008)

The order of $\mathrm{PCBi}$ abundance was $\mathrm{CB} 52>\mathrm{CB} 101>\mathrm{CB} 28>\mathrm{CB} 153>\mathrm{CB} 138>\mathrm{CB} 118$ > CB180 (Table SM.8). $\sum$ PCB-DL represented only 8 to $12 \%$ of the total PCBs. Among the 4 non-ortho substituted congeners, that share a structural similarity and toxic mode of action with polychlorinated dibenzo-p-dioxins, only CB77 and CB81 were detected at a few $\mathrm{pg} \mathrm{m}^{-3}$ with a frequency approximately $10 \%$. Both congeners were the most abundant coplanars, and this has been found to be the case in the commercial Aroclor and Clophen mixtures (Schulz et al., 1989) and in indoor air (Kohler et al., 2002). However, toxic effects such as endocrine disruption are also associated with other congeners within the group (Caserta et al., 2008).

The occurrence of PBDEs depends on the congeners considered, and the concentrations were low, from 0.001 to $0.016 \mathrm{ng} \mathrm{m}^{-3}$ as $\sum 8$ PBDEs. PBDE concentrations were 10- to 30-fold lower than PCBs. These concentrations are in accordance with total air concentrations found in the Paris centre in 2008-2009 (Tlili et al., 2012) and in Munich (Germany) in 2008 (Fromme et al., 2009).

BDE47 was quantified with a frequency up to $100 \%$, whereas BDE209 was detected in only $50 \%$ of the samples. A higher LOQ for BDE209 compared to BDE47 could contribute to such results. Two different potential sources of PBDEs were reported in urban ambient air, in Taiwan: the lighter brominated PBDEs were mainly originated from indoor air, while their highly brominated ones were attributed to combustion sources, such as vehicles (Wang et al., 2011). .

HCB and PeCB were detected in $100 \%$ of samples and displayed low concentrations, < 
$0.06 \mathrm{ng} \mathrm{m}^{-3}$. HCB production and commercialisation in Europe ceased in 1993, however it is still released into the environment as a by-product or impurity from the manufacture of chlorinated solvents, aromatics and pesticides. The European Chlorinated Solvent Association reported that 4000 tons of $\mathrm{HCB}$ were produced in Europe for 1996, during the manufacture of tetrachlorethylene and that over 99\% were incinerated at high temperature (Bonnomet et al., 2011). Another potential source of HCB to the environment is from the bioisomerization of lindane in agricultural soil (Waliszewski, 1993).

BPA was quantified in $75 \%$ of the samples and at low concentrations, ranging from 0.01

254

to $0.1 \mathrm{ng} \mathrm{m}^{-3}$. However, these results need to be confirmed because of low recoveries of the deuterated internal standard, owing to the deuterium/hydrogen exchange in hydroxyl groups when BPA-D ${ }_{16}$ was dissolved into a protic solvent such as methanol/water (BallesterosGomez et al., 2009).

\subsection{Spatial trends}

\subsubsection{Urban centre/suburban area (Paris/Lognes 2011/2012)}

Despite the high population density of 20000 inhabitants per $\mathrm{km}^{-2}$ in the Paris area (urban) versus 4400 inhabitants per $\mathrm{km}^{-2}$ at Lognes (suburban; $20 \mathrm{~km}$ from the sampling site of Paris), differences between ambient air concentrations at the two sampling sites were minor (Table 1). No differences were observed for PAHs, APs, PBDEs, HCB and PeCB. For PCBi and PAEs, the concentrations were two times lower at the suburban site than at the urban site $(\mathrm{p}<0.05)$. Thus, PCBs and PAEs showed an urban signature, whereas AP, PBDE and PAH sources were more distributed along the urban-suburban transect. In the Great Lakes basin (USA), PCBs opposite to PAHs showed a strong urban signature (Hafner and Hites, 2003).

For PAHs, the source regions were less distinct as the molecular weight of the compounds increased. Indeed, the PAHs in gaseous phase are more susceptible than those 
adsorbed on particles to degradation via reaction with $\mathrm{OH}$-radical, ozone and $\mathrm{NO}_{\mathrm{X}}$ or photolysis. For FLU, PHE, FTH and PYR well known to be emitted from gasoline engine, coal combustion and coke ovens, atmospheric lifetime under $\mathrm{OH}$-reaction varied from $26 \mathrm{~h}$ (FLU), to $5.6 \mathrm{~h}$ (FHE) and 3-5 h (FLU and PYR) (Atkinson and Arey, 1994). As a major source of OH-radicals in the atmosphere is the photolysis of ozone (Alvarez et al., 2013), the degradation potentials were estimated by ozone concentrations at the urban and the suburban site. They remained very similar as no differences were observed in ozone concentrations (Table SM.1).

For APs, wastewater treatment plants, usually located outside urban areas, were identified as a major source to ambient air during water-air exchange processes (Salgueiro-González et al., 2015).

Population density is a major factor impacting semi-volatile organic compound emissions in urban area as reported in a study in USA that noted indoor sources as the predominant factor influencing outdoor ambient air concentrations in densely populated areas (Rudel and Perovich, 2009). Indeed, in a major UK conurbation, the principal contemporary source of PCBs appears to be the ventilation of indoor air (Jamshidi et al., 2007). Moreover, emissions from indoor air to outdoors for BDE209 and sum of BDE28, 47, 99, and 153, were roughly estimated to represent close to $90 \%$ of total emissions to outdoor air in Sweden, indicating that contaminated indoor air is an important source of PBDE contamination (Björklund et al., 2012).

However, Lognes is located under prevailing westerly winds (frequency $>25 \%$ ) passing first over the Paris centre. Thus, recirculation of the contaminated air mass over the urban zone can also impact the contamination level at the suburban site located $20 \mathrm{~km}$ far from the urban site and under the air mass plume. Similarly, in the UK, a direct correlation between wind direction and PCB ambient air concentration was observed, in accordance with inputs 
from winds passing over the Birmingham city centre ( $3 \mathrm{~km}$ away from the sampling site) because the main source of tri- and tetra-chlorinated congeners is a non-equilibrium, shortrange transport (Currado and Harrad, 2000).

\subsubsection{Urban centre/forest area (Paris/Fontainebleau 2010/2011)}

Spatial differences of compound concentrations were observed from the urban site to the forest site, $56.5 \mathrm{~km}$ apart $(\mathrm{p}<0.05)$ (Table 2), with decreases ranging from 2- to 5-fold, according to the compounds.

Differences were clearly shown for $\sum 7 \mathrm{PAEs}$ (concentration ratio between the urban and the forest site $=5, \mathrm{p}<0.001$, Mann-Whitney test) and APs (ratio $=3, \mathrm{p}<0.05)$ and at a lower magnitude for $\sum 8 \mathrm{PAHs}$ and $\sum \mathrm{PCBi}$ (ratio $=2, \mathrm{p}<0.2$ ). In contrast, no differences were observed for $\sum 8 \mathrm{PBDEs}, \mathrm{HCB}$ and $\mathrm{PeCB}$, as previously observed for the urban/suburban sites.

Several processes might explain that spatial distribution. First, emissions related to high building density in urban areas might constitute the major source of PAEs and APs to ambient air. Indeed, in California (USA), of all of the chemicals studied in paired indoor and outdoor air samples, most supported the hypothesis of dominant indoor sources except for PAHs, which had a significant outdoor contribution (Rudel et al., 2010). However, in Stockholm (Sweden) the indoor environment contributes only about $25 \%$ of BDE209 to the air pollution load (Cousins et al., 2014) suggesting the existence of additional sources in the outdoor environment.

Less marked variations in concentrations of PCBs and PBDEs between the urban and the forest area were consistent with their persistence far away from their emission sources, with half-lives under photo-degradation conditions ranging from 3 to $120 \mathrm{~d}$ for PCBs (Bunce et al., 1989) and from 2 to $94 \mathrm{~d}$ for PBDEs (Wania and Dugani, 2003). In the Toronto area (Canada), data from PUF passive samplers showed that PBDEs were fairly uniform along an 
urban-rural transect, in accordance with our observations (Harner et al., 2006). In the same area, $95 \%$ of $\mathrm{PCB}$ and $70 \%$ of PBDE emissions undergo atmospheric transport from the city, the urban air plume reaching about $50 \mathrm{~km}$ in the direction of prevailing winds (Csiszar et al., 2014).

Opposite, PAEs and APs were characterised by short half-lives under photodegradation in ambient air, from $5 \mathrm{~h}$ to $18 \mathrm{~d}$ for PAEs, DEHP being more persistent than low molecular weight PAEs (Staples et al., 1997), and from 10 to $15 \mathrm{~h}$ for APs (Neamţu and Frimmel, 2006), leading to a decrease of their ambient air concentrations in the absence of local emission sources, which is documented by the detection of OP in rain and snow (Fries and Püttmann, 2004)

Concerning PAH concentrations, the small differences found between the 2 sites can be supported by a higher degradation in urban site related to elevate $\mathrm{OH}$-radical, ozone and $\mathrm{NO}_{\mathrm{X}}$ concentrations compared to the forest site. As a matter of fact, for FLU, PHE and FTH, a major removal mechanism from the gaseous phase by reaction with $\mathrm{OH}$ radicals in temperate atmosphere has been reported (Halsall, 2001).

Moreover, we observed an increase spatial homogeneity in winter $\left(1.93 \mathrm{ng} \mathrm{m}^{-3}\right.$ - urban site $/ 1.18 \mathrm{ng} \mathrm{m}^{-3}$ - forest site) compared to summer $\left(0.918 \mathrm{ng} \mathrm{m}^{-3}\right.$ - urban site/0.215 $\mathrm{ng} \mathrm{m}^{-3}$ forest site) (Table 2). A similar result was observed in Toronto (Canada) as emissions from domestic heating, with a large part played by natural gas (94\%) in urban area, corresponded to relatively low PAH emissions, compared to gasoil or wood, and lead to a greater increase in the rural compared to the urban concentrations in winter (Melymuk, 2012). Last, the vicinity of main highways crossing the forest area could contribute to local PAH emissions.

For HCB a steady concentration of approximately $0.05 \mathrm{ng} \mathrm{m}^{-3}$ was found, suggesting that there is no major primary source of $\mathrm{HCB}$ in the Paris area. Opposite, a spatial variation of $\mathrm{HCB}$ in air from an urban-rural transect across Tianjin (China) was shown, related to 
unintentionally in course of substantial chlor-alkali production ((Zheng et al., 2010).

\subsection{Temporal trends}

\subsubsection{Summer/winter variations}

Clear variations for the three sites were observed between summer and winter for PAHs, APs, PAEs and PCBs (Table 1 and Table 2). The most marked difference was found for BaP concentrations, with summer/winter increases up to 14-fold. For the $\sum 8 \mathrm{PAHs}$, a 2- to 5-fold concentration increase in the winter of 2011 and a 2-fold increase in the winter of 2012 were found. The winter season corresponds to lower degradation processes and to high domestic heating activities, that contributes to explain the summer/winter differences. Photochemical reactions of PAHs may constitute important decay routes for these compounds in the atmosphere (Albaigés et al., 1991). A main source of OH-radicals that oxidize compounds in the atmosphere, being the photolysis of ozone (Alvarez et al., 2013), a 2- to 3-fold decrease of ozone concentration in winter due to the attenuation of solar radiation (Table SM.1) could result to a decrease in PAH photolysis.

In contrast, OP concentrations decreased 4- to 7-fold in the winter, depending on the sites $(\mathrm{p}<0.05)$. NP concentrations showed lower discrepancies than OP, with a 3- to 4-fold decrease in the winter of 2011 and no variations in the winter 2012. NP and OP exhibited seasonal dependence with higher gas-phase concentrations during summer than during fall and early winter in the lower Hudson river estuary (USA), suggesting that temperature is a driving factor for their atmospheric occurrence (Van Ry et al., 2000)

The variations of PCB and DEHP concentrations were similar to that of APs, with a 2- to 7-fold decrease in the winter. However, CB52 which represent a low molecular weight PCB displayed maximal decrease whereas CB153, a heavier and less volatile congener, showed minor variation. A highly significant relationship between temperature and partial pressure of 
PCBs, PBDEs and PAHs was reported in the ambient air of Toronto (Canada), their dominant emissions originated from temperature-controlled processes such as volatilisation from local sources under warm temperatures and condensation/deposition under cold temperature (Melymuk et al., 2012).

PBDE concentrations varied little. The restriction in uses for PBDEs which lead to a decrease in emission sources, coupled to their persistence in the environment could contribute to the background level observed, this result being confirmed by low variation of concentrations along the transect urban/suburban/forest area.

Among the compounds emitted by combustion and industrial processes, only $\mathrm{HCB}, \mathrm{PeCB}$ and FLU remained steady over the year at the three sites. This is consistent with the lack of a major primary source for $\mathrm{HCB}$ and PeCB, whereas FLU has been identified as a good marker of emission from diesel vehicles (Fang et al., 2004) that prevail among road traffic in France and remain constant throughout the year. Moreover, degradation processes by atmospheric reactive species reported inside samplers (Menichini, 2009; Melymuk et al., 2014), even for compounds adsorbed on particles (Menichini, 2009), can lead to underestimate EDC concentrations in the two phases, particularly for the summer period.

\subsubsection{Pollutant phase partitioning}

The average distribution in the gaseous phase for the different compounds in summer and winter is shown in Fig. 2. In the summer, the high outdoor temperature (approximately $20{ }^{\circ} \mathrm{C}$ ) and low PM10 concentrations $\left(<22 \mu \mathrm{g} \mathrm{m}^{-3}\right)$, in contrast to the winter season with low temperatures $\left(<6.5^{\circ} \mathrm{C}\right.$ ) and high PM10 concentrations (up to $38 \mu \mathrm{g} \mathrm{m}{ }^{-3}$ ) (Table SM1), leads to the prevalence of most compounds in the gaseous phase. Thus, the proportions of the different APs and PCBs compounds in the gaseous phase were always $>50 \%$ of the total concentrations and were often up to $100 \%$. Other compounds such as DEHP tended to 
increase in the particulate phase, up to $80 \%$ in the cold season (Table 1 and 2). However, in summer, the high proportion of DEHP in gaseous form was more linked to the increase of its gaseous phase concentration (up to 32-fold at the urban area) than to the decrease of its particle phase concentration (2-fold).

Because of their high volatility (vapour pressure, VP, $0.63 \mathrm{~Pa}$ at $25^{\circ} \mathrm{C}$ for $\mathrm{NP}$ ) compared to the other EDCs, APs prevailed in the gaseous phase in all seasons. A similar phase distribution was reported at an urban site of Germany, with NP concentrations ranging from 0.15 to $1.0 \mathrm{ng} \cdot \mathrm{m}^{-3}$ in the gaseous phase and from 0.002 to $0.117 \mathrm{ng} \cdot \mathrm{m}^{-3}$ in the particulate phase (Berkner et al., 2004).

PCBs occurred in the gaseous phase, from $97 \%$ for the lower chlorinated congeners to $12 \%$ for the highly chlorinated ones as they display a wide range of VP (from 5.8 to $0.00005 \mathrm{~Pa}$ ) (Table SM.9). A prevailing occurrence in the gaseous phase associated with a decreasing concentration of the highly chlorinated congeners in winter was reported at an industrial location in North China (Li et al., 2015).

HCB (VP: $2.3 \times 10^{-3} \mathrm{~Pa}$ ) was only detected in the gaseous phase, which confirms previous observations in Ontario (Canada) (Lane et al., 1992).

PBDEs were in the gaseous phase from $34 \%$ to $99 \%$. These results are consistent with previous studies that indicated that tri- to hepta-BDEs dominated the gaseous phase, accounting for $77 \%$ of the total PBDE levels (Tlili et al., 2012).

Except for $\mathrm{BaP}, \mathrm{BaA}$ and BghiP, which are mainly associated with particles, PAHs were predominantly in the gaseous phase (Fig. 2). In summer, the most volatile PAHs (VP from 4.1 $\mathrm{Pa}$ to $5.7 \times 10^{-2} \mathrm{~Pa}$ ) were found at rates up to $100 \%$ in the gaseous phase, whereas CHR was equally distributed in both phases. Compound occurrence in the gaseous phase decreased from summer to winter from $50 \%$ to $25 \%$ of the total concentration for CHR; whereas, for the most volatile PAHs, the gaseous phase remained the predominant phase. This is in accordance 
with literature data (Terzi and Samara, 2004; Ballesteros-Gomez et al., 2009). The molecular weight of CHR (Mw $228 \mathrm{~g} \mathrm{~mol}^{-1}$ ) corresponds to the dividing line for the distribution of PAH compounds preferentially in the gaseous or the particulate phase (Lu et al., 2008).

Direct relationships were found between $\log \mathrm{Kp}$ of EDCs and $\log \mathrm{K}_{\mathrm{OA}}\left(\mathrm{R}^{2}=0.335, \mathrm{p}<\right.$ 0.001) and also between the EDC occurrence in the gaseous phase and their log Vp $\left(\mathrm{R}^{2}=\right.$ 0.571, $\mathrm{p}<0.001$ ) for the summer period (Fig. 3, Table SM.9). Thus, Vp and $\mathrm{K}_{\mathrm{OA}}$ are relevant parameters for predicting EDC distribution in ambient air, as reported in previous studies (Falconer and Bidleman, 1994; Harner and Bidleman, 1998; Paasivirta et al., 1999).

Other environmental parameters, such as UV index or sunshine duration, size and nature of the particles and hygrometry, might interfere with EDC partitioning in ambient air (Cousins and Mackay, 2001). In addition, for FLU, PHE and FTH, a major removal mechanism from the gaseous phase, by reaction with $\mathrm{OH}$ radicals, in temperate atmosphere, has been reported, (Halsall et al., 2001).

\subsubsection{Two year variations at the Paris site - impact of ambient parameters (temperature and PM10)}

Annual EDC concentrations in ambient air in the Paris centre (Table 1 and Table 2) were about two-fold lower for the second campaign (2011/2012) than for the first one (2010/2011) for PAEs, APs and PBDEs, and there was less variation for PCBs and PAHs. Inter-annual variations were mainly characterised by lower summer concentrations during the campaign 2011/2012. The average air temperature higher in summer $2010\left(20.9^{\circ} \mathrm{C}\right)$ than in summer $2011\left(19.2^{\circ} \mathrm{C}\right)$ was in favour of volatilisation particularly for the most volatile compounds like OP, NP, FLU, PHE and CB52, which presented higher gaseous phase concentrations (Table 1 and Table 2).

To enhance knowledge about the influence of ambient parameters upon EDC variability, 
a principal component analysis (PCA) was performed at a significance level of 95\%. EDC concentrations in the ambient air of the urban area were examined in relation to outdoor temperature and PM10 concentrations. PM10 that are from 2 origins, local and regional, may increase with emissions, thermal inversion phenomenon, low wind speed, and air mass recirculation in continental environments and anti-cyclonic conditions with East/North-East wind direction. Two predominant compounds within each chemical group, one of low molecular weight and one of high molecular weight were considered to perform the PCA analysis. Two clusters were identified corresponding to winter and summer samples (Fig. 4).

The correlation matrix for $\mathrm{p}<0.05$ (Table 3) showed a direct correlation between temperature and CB52 or CB153, OP and DEP. In the summer of 2011, the ambient temperature reached a higher value than in the summer of 2012, which can favour volatilisation from contaminated sites and materials and contribute to the explanation of higher air concentrations for PAEs, APs and PBDEs in 2011. On the contrary, a positive correlation between $\mathrm{BaP}$ and PM10 concentrations and a negative correlation between $\mathrm{BaP}$ and temperature were found. This result is a consequence of their high production and emission levels in winter and their tendency to be adsorbed upon particles. High PAH concentrations and high PM10 levels during poor vertical mixing associated with the strong barrier of surface inversions were reported in ambient air from rural residential areas in southern Germany (Bari et al., 2010). and provides useful insights into the growing concern regarding chronic exposure to these compounds. The human exposure to indoor air contamination in France was estimated via 
indoor air concentration data. But, due to the lack of data for outdoor air concentrations (more especially total and gaseous phase concentrations), most of the studies concerning the particles, it remains difficult to estimate the exposure from outdoor air.

The high volume sampling conditions allowed the quantification of all EDCs except TBBPA. Our findings are consistent with molecular properties, environmental conditions and published literature.

Environmental data about ambient air contamination improves the knowledge of distribution variability that depends on location characteristics (urban, suburban, forest) and mainly on temperature conditions (summer, winter). The general trend for seasonal variations was of lower concentrations in winter for most compounds, except for PAHs and in particular $\mathrm{BaP}$, that depend i) on their lower photochemical reaction linked to the increase in the adsorbed form ii) on the decrease in atmospheric reactive species like ozone and iii) on the increase in combustion processes, during the cold season.

Compound distribution between gaseous and particulate phases depends on compound properties such as $\log \mathrm{K}_{\mathrm{OA}}$ and on particulate aerosol concentrations and ambient air temperature. The EDCs studied are largely distributed in the gaseous phase, which leads to the ubiquity of these SVOCs, even far away from their emission source locations.

Our study highlights priority SVOCs that may be considered for monitoring air quality or for the control of diffuse emission sources. Thus, molecules belonging to the PAE and AP families which are already listed as priority compounds for the protection of aquatic environments (DCE - 2000), are both ubiquitous and relatively abundant in the atmosphere. In Europe, PAHs are regulated both in ambient air and emissions. The objective of this regulation is to assess the population exposure to air pollution and to improve air quality. Therefore, some PAE compounds like DEHP and some APs could be associated with PAH monitoring. 


\section{Acknowledgments:}

This work was supported by the French Agency for Food, Environmental and Occupational

Health \& Safety -ANSES, under the frame of the "Programme National de Recherche sur les

Perturbateurs Endocriniens" (PNRPE). Financial contributions were given by the Agence de

Scientifique et Technique du Bâtiment - CSTB (Grant $n^{\circ}$ C11641). We are grateful to the

Association de Surveillance de la qualité de l'air en Île-de-France - Airparif, for providing data about PM10 and for their assistance in climatic parameter interpretation. Technical

\section{References}

508

509

510

511

512

513

514

515

516

517

518

519

520

521

522

523

524

525

Albaigés, J., Bayona, J.M., Fernandez, P., Grimalt, J., Rosell, A., Simó, R., 1991. Vapor-particle partitioning of hydrocarbons in Western Mediterranean urban and marine atmospheres. Microchimica Acta 104, 13-27.

Alliot, F., Moreau-Guigon, E., Bourges, C., Desportes, A., Teil, M.-J., Blanchard, M., Chevreuil, M., 2014. A multi-residue method for characterization of endocrine disruptors in gaseous and particulate phases of ambient air. Atmos. Environ. 92, 1-8.

Alvarez, E.G., Amedro, D., Afif, C., Gligorovski, S., Schoemaecker, C., Fittschen, C., Doussin, J.-F., Wortham, H., 2013. Unexpectedly high indoor hydroxyl radical concentrations associated with nitrous acid. P. Natl. Acad. Sc. 110, 13294-13299.

Anezaki, K., Kannan, N., Nakano, T., 2015. Polychlorinated biphenyl contamination of paints containing polycyclic- and Naphthol AS-type pigments. Environ. Sci. Pollut. R. 22, 14478-14488.

ATEP9870017A, N., 1998. Arrêté du 2 février 1998 relatif aux prélèvements et à la consommation d'eau ainsi qu'aux émissions de toute nature des installations classées pour la protection de l'environnement soumises à autorisation. Legifrance. http://www.legifrance.gouv.fr/affichTexte.do?cidTexte=JORFTEXT000000204891\&dateTexte $=\&$ cat egorieLien=id, access date June 062015.

Atkinson, R., Arey, J., 1994. Atmospheric chemistry of gas-phase polycyclic aromatic hydrocarbons: formation of atmospheric mutagens. Environ. Health Persp 102, 117-126.

Ballesteros-Gomez, A., Rubio, S., Perez-Bendito, D., 2009. Analytical methods for the determination of bisphenol A in food. J. Chromatogr. A 1216, 449-469.

Bari, M.A., Baumbach, G., Kuch, B., Scheffknecht, G., 2010. Particle-phase concentrations of polycyclic aromatic hydrocarbons in ambient air of rural residential areas in southern Germany. Air Qual. Atmos. Health 3, 103-116.

Benachour, N., Moslemi, S., Sipahutar, H., Seralini, G.E., 2007. Cytotoxic effects and aromatase inhibition by xenobiotic endocrine disrupters alone and in combination. Toxicol. Appl. Pharm. 222, 129-140.

Berkner, S., Streck, G., Herrmann, R., 2004. Development and validation of a method for determination of trace levels of alkylphenols and bisphenol $A$ in atmospheric samples. Chemosphere 54, 575-584.

Birgul, A., Tasdemir, Y., 2015. Concentrations, Gas-Particle Partitioning, and Seasonal Variations of 
Polycyclic Aromatic Hydrocarbons at Four Sites in Turkey. Arch. Environ. Con. Tox. 68, 46-63.

Björklund, J.A., Thuresson, K., Cousins, A.P., Sellström, U., Emenius, G., de Wit, C.A., 2012. Indoor Air Is a Significant Source of Tri-decabrominated Diphenyl Ethers to Outdoor Air via Ventilation Systems. Environ. Sci. Technol. 46, 5876-5884.

Blanchard, M., Teil, M.J., Chevreuil, M., 2006. The Seasonal Fate of PCBs in Ambient Air and Atmospheric Deposition in Northern France. J. Atmos Chem. 53, 123-144.

Bonnomet, V., Bisson, M., Gillebaert, F., 2011. Hexachlorobenzene. Ineris. www.ineris.fr/substances/fr/substance/getDocument/2792, access date 10/01/2015.

Brignon, 2005. Pentachlorobenzene. INERIS. http://www.ineris.fr/rsde/fiches/fiche pentachlorobenzene.pdf access date June 082015.

Bunce, N.J., Landers, J.P., Langshaw, J.A., Nakai, J.S., 1989. An assessment of the importance of direct solar degradation of some simple chlorinated benzenes and biphenyls in the vapor phase. Environ. Sci. Technol. 23, 213-218.

Caserta, D., Maranghi, L., Mantovani, A., Marci, R., Maranghi, F., Moscarini, M., 2008. Impact of endocrine disruptor chemicals in gynaecology. Hum. Reprod. update 14, 59-72.

Cladière, M., Gasperi, J., Lorgeoux, C., Bonhomme, C., Rocher, V., Tassin, B., 2013. Alkylphenolic compounds and bisphenol A contamination within a heavily urbanized area: case study of Paris. Environ. Sci. Pollut. R. 20, 2973-2983.

Cousins, A.P., Holmgren, T., Remberger, M., 2014. Emissions of two phthalate esters and BDE 209 to indoor air and their impact on urban air quality. Sci. Total Environ. 470-471, 527-535.

Cousins, I.T., Mackay, D., 2001. Gas-particle partitioning of organic compounds and its interpretation using relative solubilities. Environ. Sci. Technol. 35, 643-647.

Csiszar, S.A., Diamond, M.L., Daggupaty, S.M., 2014. The Magnitude and Spatial Range of CurrentUse Urban PCB and PBDE Emissions Estimated Using a Coupled Multimedia and Air Transport Model. Environ. Sci. Technol. 48, 1075-1083.

Currado, G.M., Harrad, S., 2000. Factors Influencing Atmospheric Concentrations of Polychlorinated Biphenyls in Birmingham, U.K. Environ. Sci. Technol. 34, 78-82.

de Wit, C.A., Herzke, D., Vorkamp, K., 2010. Brominated flame retardants in the Arctic environment -- trends and new candidates. Sci. Total Environ. 408, 2885-2918.

Deca-BDE, 2012. Factsheet Brominated flame retardant. . Bromine Science and Environmental Forum. http://www.bsef.com/uploads/Deca factsheet 25-10-2012.pdf, access date June 062015.

Decree, July 08 2010. Arrêté du 8 juillet 2010 modifiant l'arrêté du 25 janvier 2010 relatif aux méthodes et critères d'évaluation de l'état écologique, de l'état chimique et du potentiel écologique des eaux de surface pris en application des articles R. 212-10, R. 212-11 et R. 212-18 du code de l'environnement. Legifrance. http://www.legifrance.gouv.fr/eli/arrete/2010/7/8/DEV01017167A/jo/article 2, access date June 06 2015.

Directive2003/11/EC, Directive 2003/11/EC of the European Parliament and of the Council of 6 February 2003 amending for the 24th time Council Directive 76/769/EEC relating to restrictions on the marketing and use of certain dangerous substances and preparations (pentabromodiphenyl ether, octabromo-diphenyl ether). http://eur-lex.europa.eu/LexUriServ/LexUriServ.do?uri=OJ:L:2003:042:0045:0046:EN:PDF, access date November 2015.

EEA, 2013. EU emission inventory report 1990-2011 under the UNECE Convention on LRTAP. Technicol report №10. European Environment Agency. http://www.eea.europa.eu/publications/euemission-inventory-report-Irtap access date June 062015.

Falconer, R.L., Bidleman, T.F., 1994. Vapor pressures and predicted particle/gas distributions of polychlorinated biphenyl congeners as functions of temperature and ortho-chlorine substitution. Atmos. Environ. 28, 547-554.

Fang, G.-C., Chang, C.-N., Wu, Y.-S., Fu, P.P.-C., Yang, I.-L., Chen, M.-H., 2004. Characterization, identification of ambient air and road dust polycyclic aromatic hydrocarbons in central Taiwan, Taichung. Sci. Total Environ. 327, 135-146.

Fries, E., Püttmann, W., 2004. Occurrence of 4-Nonylphenol in rain and snow. Atmos. Environ. 38, 2013-2016.

Fromme, H., Körner, W., Shahin, N., Wanner, A., Albrecht, M., Boehmer, S., Parlar, H., Mayer, R., Liebl, B., Bolte, G., 2009. Human exposure to polybrominated diphenyl ethers (PBDE), as evidenced by data from a duplicate diet study, indoor air, house dust, and biomonitoring in Germany. Environ. Int. 35, 1125-1135. 
Fujii, M., Shinohara, N., Lim, A., Otake, T., Kumagai, K., Yanagisawa, Y., 2003. A study on emission of phthalate esters from plastic materials using a passive flux sampler. Atmos. Environ. 37, 54955504.

Granier, L.K., Chevreuil, M., 1997. Behaviour and spatial and temporal variations of polychlorinated biphenyls and lindane in the urban atmosphere of the Paris area. France. Atmos. Environ. 31, 3787-3802.

Gustafson, K.E., Dickhut, R.M., 1997. Particle/Gas Concentrations and Distributions of PAHs in the Atmosphere of Southern Chesapeake Bay. Environ. Sci. Technol. 31, 140-147.

Hafner, W.D., Hites, R.A., 2003. Potential sources of pesticides, PCBs, and PAHs to the atmosphere of the Great Lakes. Environ. Sci. Technol. 37, 3764-3773.

Halsall, C.J., Sweetman, A., Barrie, L., Jones, K.C., 2001. Modelling the behaviour of PAHs during atmospheric transport from the UK to the Arctic. Atmos. Environ. 35, 255-267.

Harner, T., Bidleman, T.F., 1998. Octanol Air Partition Coefficient for Describing Particle/Gas Partitioning of Aromatic Compounds in Urban Air. Environ. Sci. Technol. 32, 1494-1502.

Harner, T., Shoeib, M., Diamond, M., Ikonomou, M., Stern, G., 2006. Passive sampler derived air concentrations of PBDEs along an urban-rural transect: Spatial and temporal trends. Chemosphere 64, 262-267.

Huang, Y.Q., Wong, C.K., Zheng, J.S., Bouwman, H., Barra, R., Wahlstrom, B., Neretin, L., Wong, M.H., 2012. Bisphenol A (BPA) in China: a review of sources, environmental levels, and potential human health impacts. Environ. Int. 42, 91-99.

IEPA/APC/85-003, Illinois, Environmental Protection, A., Ambient Air Monitoring, S., 1985. Project plan for the sampling and analysis of polychlorinated biphenyls in the Lake Calumet area of southeast Chicago. Illinois Environmental Protection Agency, Ambient Air Monitoring Section, Springfield, III.

Jamshidi, A., Hunter, S., Hazrati, S., Harrad, S., 2007. Concentrations and chiral signatures of polychlorinated biphenyls in outdoor and indoor air and soil in a major UK conurbation. Environ. Sci. Technol. 41, 2153-2158.

Katsoyiannis, A., Sweetman, A.J., Jones, K.C., 2011. PAH molecular diagnostic ratios applied to atmospheric sources: a critical evaluation using two decades of source inventory and air concentration data from the UK. Environ. Sci. Technol. 45, 8897-8906.

Kohler, M., Zennegg, M., Waeber, R., 2002. Coplanar polychlorinated biphenyls (PCB) in indoor air. Environ. Sci. Technol. 36, 4735-4740.

Lane, D.A., Johnson, N.D., Hanley, M.J.J., Schroeder, W.H., Ord, D.T., 1992. Gas-and particle-phase concentrations of. alpha.-hexachlorocyclohexane,. gamma.-hexachlorocyclohexane, and hexachlorobenzene in Ontario air. Environ. Sci. Technol. 26, 126-133.

Li, Z.-Y., Zhang, Y.-L., Chen, L., 2015. Seasonal Variation and Gas/Particle Partitioning of PCBs in Air from Central Urban Area of an Industrial Base and Coastal City -Tianjin, China. Aerosol Air Qual. Res. 15, 1059-1071.

Liang, Y., Xu, Y., 2014. Emission of Phthalates and Phthalate Alternatives from Vinyl Flooring and Crib Mattress Covers: The Influence of Temperature. Environ. Sci. Technol. 48, 14228-14237.

Lu, H., Zhu, L., Chen, S., 2008. Pollution level, phase distribution and health risk of polycyclic aromatic hydrocarbons in indoor air at public places of Hangzhou, China. Environ. Pollut.152, 569-575.

Mari, M., Schuhmacher, M., Feliubadaló, J., Domingo, J.L., 2008. Air concentrations of PCDD/Fs, PCBs and PCNs using active and passive air samplers. Chemosphere 70, 1637-1643.

Melymuk, L., Bohlin, P., Sáňka, O., Pozo, K., Klánová, J., 2014. Current Challenges in Air Sampling of Semivolatile Organic Contaminants: Sampling Artifacts and Their Influence on Data Comparability. Environ. Sci. Technol. 48, 14077-14091.

Melymuk, L., Robson, M., Helm, P.A., Diamond, M.L., 2012. PCBs, PBDEs, and PAHs in Toronto air: spatial and seasonal trends and implications for contaminant transport. Sci. Total Environ. 429, 272-280.

Menichini, E., 2009. On-filter degradation of particle-bound benzo[a]pyrene by ozone during air sampling: A review of the experimental evidence of an artefact. Chemosphere 77, 1275-1284.

Motelay-Massei, A., Ollivon, D., Garban, B., Chevreuil, M., 2003. Polycyclic aromatic hydrocarbons in bulk deposition at a suburban site: assessment by principal component analysis of the influence of meteorological parameters. Atmos. Environ. 37, 3135-3146.

Paasivirta, J., Sinkkonen, S., Mikkelson, P., Rantio, T., Wania, F., 1999. Estimation of vapor pressures, solubilities and Henry's law constants of selected persistent organic pollutants as functions of temperature. Chemosphere 39, 811-832.

Palm, A., Cousins, I.T., Mackay, D., Tysklind, M., Metcalfe, C., Alaee, M., 2002. Assessing the 
environmental fate of chemicals of emerging concern: a case study of the polybrominated diphenyl ethers. Environ. Pollut.117, 195-213.

Peijnenburg, W.J., Struijs, J., 2006. Occurrence of phthalate esters in the environment of the Netherlands. Ecotox. Environ. Safe. 63, 204-215.

Rodenburg, L.A., Guo, J., Du, S., Cavallo, G.J., 2010. Evidence for Unique and Ubiquitous Environmental Sources of 3,3'-Dichlorobiphenyl (PCB 11). Environ. Sci. Technol. 44, 2816-2821.

Rudel, R.A., Dodson, R.E., Perovich, L.J., Morello-Frosch, R., Camann, D.E., Zuniga, M.M., Yau, A.Y., Just, A.C., Brody, J.G., 2010. Semivolatile endocrine-disrupting compounds in paired indoor and outdoor air in two northern California communities. Environ. Sci. Technol. 44, 6583-6590.

Rudel, R.A., Perovich, L.J., 2009. Endocrine disrupting chemicals in indoor and outdoor air. Atmos. Environ. 43, 170-181.

Saito, I., Onuki, A., Seto, H., 2004. Indoor air pollution by alkylphenols in Tokyo. Indoor Air 14, 325332.

Salgueiro-González, N., López de Alda, M.J., Muniategui-Lorenzo, S., Prada-Rodríguez, D., Barceló, D., 2015. Analysis and occurrence of endocrine-disrupting chemicals in airborne particles. TrAC Trends in Analytical Chemistry 66, 45-52.

Schulz, D.E., Petrick, G., Duinker, J.C., 1989. Complete characterization of polychlorinated biphenyl congeners in commercial Aroclor and Clophen mixtures by multidimensional gas chromatographyelectron capture detection. Environ. Sci. Technol. 23, 852-859.

Teil, M.J., Blanchard, M., Chevreuil, M., 2006. Atmospheric fate of phthalate esters in an urban area (Paris-France). Sci. Total Environ. 354, 212-223.

Terzi, E., Samara, C., 2004. Gas-Particle Partitioning of Polycyclic Aromatic Hydrocarbons in Urban, Adjacent Coastal, and Continental Background Sites of Western Greece. Environ. Sci. Technol. 38, 4973-4978.

Tlili, K., Labadie, P., Alliot, F., Bourges, C., Desportes, A., Chevreuil, M., 2012. Polybrominated diphenyl ether dynamics in ambient air and atmospheric bulk/wet deposition in downtown Paris (France). Water Air Soil Pollut. 223, 1543-1553.

Tobiszewski, M., Namieśnik, J., 2012. PAH diagnostic ratios for the identification of pollution emission sources. Environ. Pollut.162, 110-119.

Van Ry, D.A., Dachs, J., Gigliotti, C.L., Brunciak, P.A., Nelson, E.D., Eisenreich, S.J., 2000. Atmospheric seasonal trends and environmental fate of alkylphenols in the lower Hudson River estuary. Environ. Sci. Technol. 34, 2410-2417.

Waliszewski, S.M., 1993. Residues of lindane, $\mathrm{HCH}$ isomers and $\mathrm{HCB}$ in the soil after lindane application. Environ. Pollut.82, 289-293.

Wang, L.-C., Lee, W.-J., Lee, W.-S., Chang-Chien, G.-P., 2011. Polybrominated diphenyl ethers in various atmospheric environments of Taiwan: Their levels, source identification and influence of combustion sources. Chemosphere 84, 936-942.

Wania, F., 2003. Assessing the potential of persistent organic chemicals for long-range transport and accumulation in polar regions. Environ. Sci. Technol. 37, 1344-1351.

Wania, F., Dugani, C.B., 2003. Assessing the long-range transport potential of polybrominated diphenyl ethers :a comparaison of four multimedia models. Environ. Toxicol. Chem. 22, 1252 1261.

Who, 1995. Environmental Health Criteria 172. Tetrabromobisphenol A and derivatives International Program on Chemical Safety. World Health Organization, Geneva, Switzerland. http://www.inchem.org/documents/ehc/ehc/ehc172.htm\#SubSectionNumber:1.1.2, access date June 152015.

Woodruff, T.J., 2011. Bridging epidemiology and model organisms to increase understanding of endocrine disrupting chemicals and human health effects. J. Steroid Biochem. 127, 108-117.

Wormuth, M., Scheringer, M., Vollenweider, M., Hungerbuhler, K., 2006. What are the sources of exposure to eight frequently used phthalic acid esters in Europeans? Risk analysis: an official publication of the Society for Risk Analysis 26, 803-824.

Zheng, X., Chen, D., Liu, X., Zhou, Q., Liu, Y., Yang, W., Jiang, G., 2010. Spatial and seasonal variations of organochlorine compounds in air on an urban-rural transect across Tianjin, China. Chemosphere 78, 92-98. 

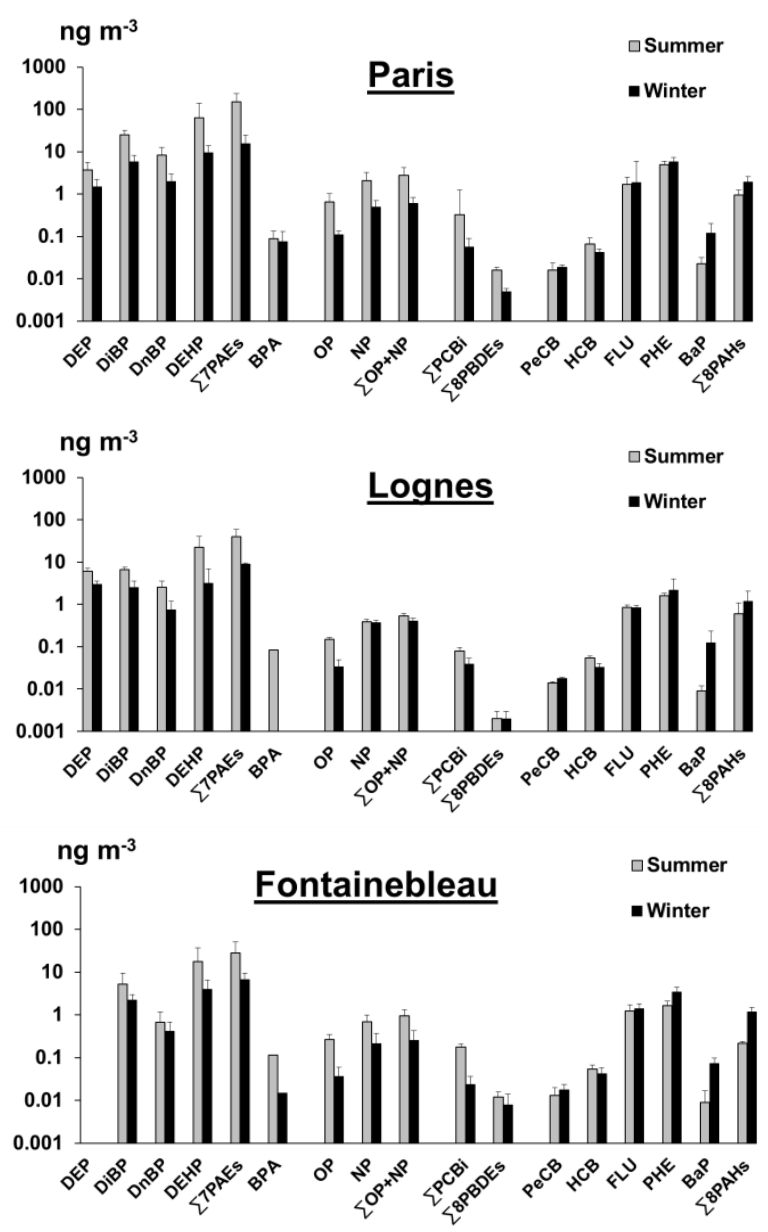

Fig. 1: Concentrations as $\mathrm{ng} \mathrm{\textrm {m } ^ { - 3 }}$ (mean $\pm \mathrm{SD}, \mathrm{n}=3$ ) of EDCs at Paris, Lognes and 715 Fontainebleau in summer and winter. 


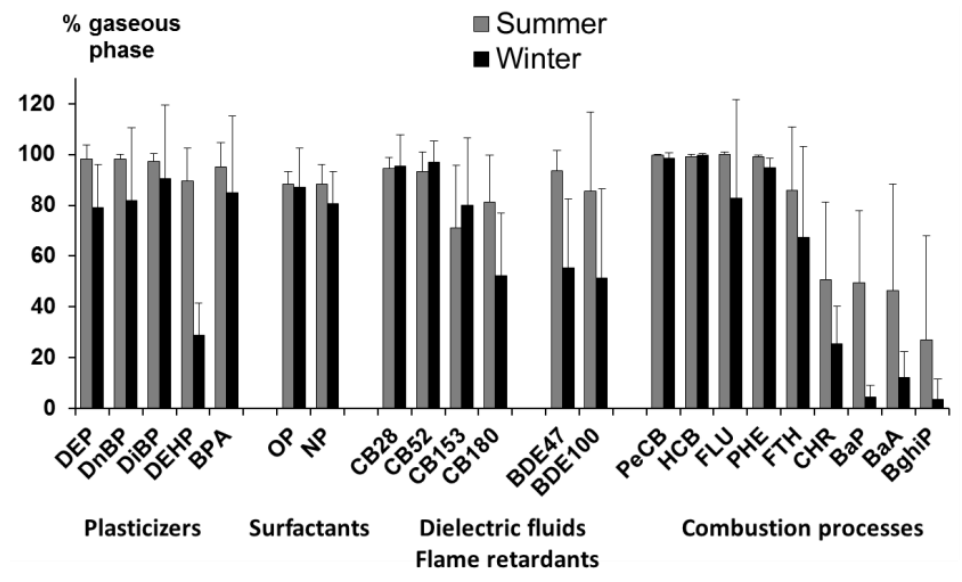

Fig. 2: Compound distribution in the gaseous phase as $\%$ of total (mean $\pm \mathrm{SD}, \mathrm{n}=9$ ), at the 721 

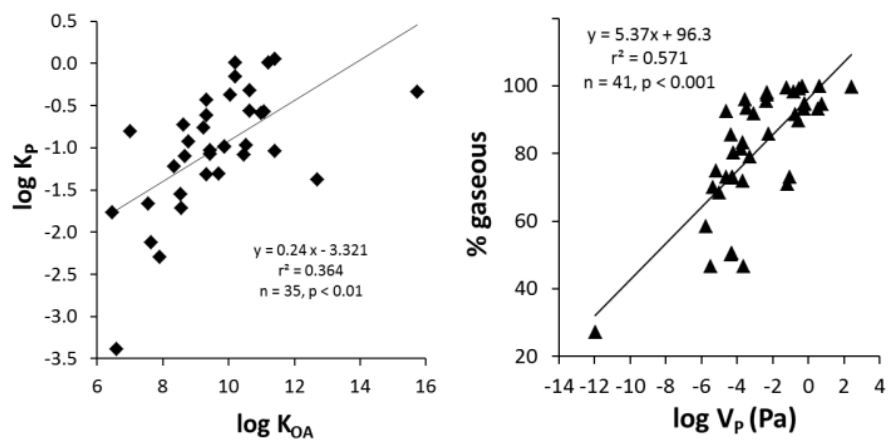

723 Fig. 3: $\log \mathrm{Kp}$ against $\log \mathrm{K}_{\mathrm{OA}}\left(\right.$ at $25^{\circ} \mathrm{C}$ ) and compound as \% gaseous phase against $\log \mathrm{Vp}$

(Pa at $25^{\circ} \mathrm{C}$ ) for the summer period, all sites included. 


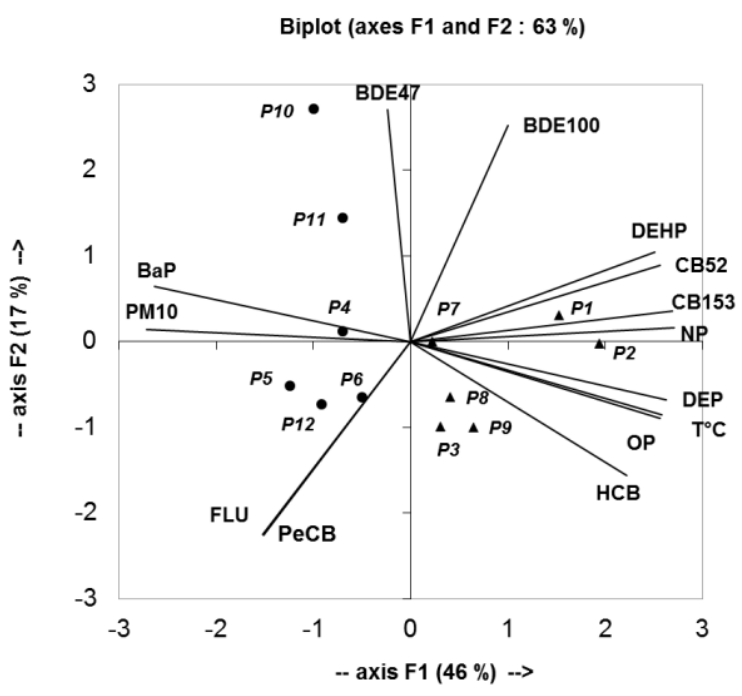

726

727 Fig. 4: PCA projections of the 12 air samples corresponding to the two sampling campaigns at 728 the Paris location ( $\Delta$ summer and $\bullet$ winter) and of the 14 variables (solid lines). 
731 as seasonal concentrations in the gaseous, the particulate phases and the total air $\left(\mathrm{ng} \mathrm{m}^{-3}\right)$ and

Annual concentration $(\mathrm{n}=6)$

\begin{tabular}{|c|c|c|c|c|c|c|c|c|c|}
\hline compound & $\begin{array}{c}\text { Total } \\
\left(\mathrm{ng} \mathrm{m}^{-3}\right)\end{array}$ & $\begin{array}{l}\text { Gaseous } \\
\left(\mathrm{ng} \mathrm{m}^{-3}\right)\end{array}$ & $\begin{array}{c}\text { Particulate } \\
\left(\mathrm{ng} \mathrm{m}^{-3}\right)\end{array}$ & $\begin{array}{c}\% \\
\text { gaseous }\end{array}$ & $\begin{array}{c}\text { Total } \\
\left(\mathrm{ng} \mathrm{m}^{-3}\right)\end{array}$ & $\begin{array}{c}\text { Gaseous } \\
\left(\mathrm{ng} / \mathrm{m}^{3}\right)\end{array}$ & $\begin{array}{c}\text { Particulate } \\
\left(\mathrm{ng} \mathrm{m}^{-3}\right)\end{array}$ & $\begin{array}{c}\% \\
\text { gaseous }\end{array}$ & $\begin{array}{c}\text { Total } \\
\left(\mathrm{ng} \mathrm{m}^{-3}\right)\end{array}$ \\
\hline & \multicolumn{9}{|c|}{ Paris } \\
\hline OP & $0.142 \pm 0.105$ & 0.191 & 0.034 & 85 & $0.225 \pm 0.082$ & 0.056 & 0.004 & 94 & $0.060 \pm 0.019$ \\
\hline NP & $0.468 \pm 0.140$ & 0.287 & 0.084 & 77 & $0.371 \pm 0.108$ & 0.541 & 0.023 & 96 & $0.564 \pm 0.095$ \\
\hline$\sum \mathrm{OP}+\mathrm{NP}$ & $0.610 \pm 0.118$ & 0.478 & 0.118 & 80 & $0.596 \pm 0.155$ & 0.597 & 0.027 & 96 & $0.624 \pm 0.101$ \\
\hline BPA & $0.05 \pm 0.05$ & 0.076 & $<L O Q$ & 100 & 0.076 & 0.039 & 0.032 & 55 & $0.071 \pm 0.057$ \\
\hline TBBPA & & $<L O Q$ & $\angle L O Q$ & - & - & 0.010 & 0.001 & 96 & $0.013 \pm 0.022$ \\
\hline FLU & $1.09 \pm 0.60$ & 1.16 & 0.001 & 100 & $1.16 \pm 0.33$ & 1.00 & 0.018 & 98 & $1.02 \pm 0.871$ \\
\hline PHE & $2.57 \pm 1.48$ & 2.35 & 0.016 & 99 & $2.37 \pm 0.56$ & 2.52 & 0.26 & 91 & $2.80 \pm 2.20$ \\
\hline $\mathrm{BaP}$ & $0.07 \pm 0.08$ & 0.006 & 0.003 & 38 & $0.009 \pm 0.003$ & 0.002 & 0.125 & 1 & $0.127 \pm 0.084$ \\
\hline$\sum 8 \mathrm{PAHs}$ & $1.05 \pm 0.61$ & 0.470 & 0.185 & 72 & $0.655 \pm 0.107$ & 0.512 & 0.930 & 36 & $1.44 \pm 0.666$ \\
\hline HCB & $0.054 \pm 0.027$ & 0.068 & $<L O Q$ & 100 & $0.068 \pm 0.03$ & 0.046 & $<L O Q$ & 100 & $0.046 \pm 0.016$ \\
\hline PeCB & $0.018 \pm 0.009$ & 0.019 & $<L O Q$ & 99 & $0.019 \pm 0.008$ & 0.022 & $<L O Q$ & 100 & $0.022 \pm 0.008$ \\
\hline CB52 & $0.047 \pm 0.022$ & 0.059 & $<L O Q$ & 100 & $0.059 \pm 0.025$ & 0.034 & $<L O Q$ & 100 & $0.035 \pm 0.014$ \\
\hline CB153 & $0.012 \pm 0.005$ & 0.015 & 0.001 & 84 & $0.016 \pm 0.004$ & 0.007 & 0.001 & 87 & $0.008 \pm 0.002$ \\
\hline$\sum \mathrm{PCBi}$ & $0.129 \pm 0.063$ & 0.169 & 0.005 & 84 & $0.170 \pm 0.068$ & 0.084 & 0.005 & 95 & $0.089 \pm 0.021$ \\
\hline$\sum \overline{\mathrm{PCB}}-\mathrm{DL}$ & $0.016 \pm 0.007$ & 0.021 & 0.005 & 94 & $0.021 \pm 0.006$ & 0.011 & 0.001 & 93 & $0.012 \pm 0.002$ \\
\hline DEP & $6.99 \pm 1.55$ & 6.69 & 0.436 & 94 & $7.13 \pm 0.55$ & 4.81 & 2.05 & 70 & $6.86 \pm 2.37$ \\
\hline DiBP & $7.85 \pm 1.60$ & 7.30 & 0.330 & 96 & $7.63 \pm 2.21$ & 8.07 & $<L O Q$ & 100 & $8.07 \pm 1.15$ \\
\hline DnBP & $2.10 \pm 0.88$ & 2.66 & 0.156 & 94 & $2.81 \pm 0.65$ & 1.39 & $<L O Q$ & 100 & $1.39 \pm 0.093$ \\
\hline DEHP & $25.1 \pm 11.4$ & 21.8 & 8.9 & 71 & $30.7 \pm 14.7$ & 3.62 & 15.8 & 19 & $19.5 \pm 4.0$ \\
\hline$\sum 7$ Phthalates & $36.3 \pm 17.1$ & 40.2 & 10.0 & 80 & $50.2 \pm 12.2$ & 18.1 & 4.2 & 81 & $22.4 \pm 3.4$ \\
\hline BDE47 & $0.0022 \pm 0.0019$ & 0.001 & 0.0001 & 83 & 0.001 & 0.001 & 0.003 & 23 & $0.004 \pm 0.003$ \\
\hline BDE209 & & $<L O Q$ & $<L O Q$ & & - & $<L O Q$ & $<L O Q$ & - & - \\
\hline \multirow[t]{2}{*}{$\sum 8$ PBDEs } & $0.0043 \pm 0.0051$ & 0.0011 & 0.0003 & 77 & $0.0015 \pm 0.0004$ & 0.0009 & 0.006 & 13 & $0.007 \pm 0.006$ \\
\hline & \multicolumn{9}{|c|}{ Lognes } \\
\hline $\mathrm{OP}$ & $0.94 \pm 0.066$ & 0.129 & 0.025 & 84 & $0.154 \pm 0.015$ & 0.030 & 0.004 & 89 & $0.034 \pm 0.015$ \\
\hline 4-NP & $0.38 \pm 0.12$ & 0.354 & 0.035 & 90 & $0.389 \pm 0.053$ & 0.314 & 0.059 & 84 & $0.373 \pm 0.246$ \\
\hline$\sum \mathrm{OP}+\mathrm{NP}$ & $0.48 \pm 0.17$ & 0.483 & 0.060 & 89 & $0.543 \pm 0.052$ & 0.344 & 0.063 & 85 & $0.407 \pm 0.256$ \\
\hline $\mathrm{BPA}$ & & 0.084 & $<L O Q$ & 100 & 0.084 & $<L O Q$ & $<L O Q$ & 85 & \\
\hline TBBPA & & $<L O Q$ & $\angle L O Q$ & - & - & 0.008 & $<L O Q$ & 98 & $0.008 \pm 0.01$ \\
\hline FLU & $0.84 \pm 0.36$ & 0.853 & 0.001 & 100 & $0.853 \pm 0.113$ & 0.814 & 0.014 & 98 & $0.828 \pm 0.012$ \\
\hline PHE & $1.9 \pm 0.96$ & 1.56 & 0.024 & 99 & $1.58 \pm 0.224$ & 2.000 & 0.194 & 91 & $2.19 \pm 1.81$ \\
\hline $\mathrm{BaP}$ & $0.067 \pm 0.075$ & 0.008 & 0.001 & 89 & $0.009 \pm 0.003$ & 0.002 & 0.123 & 1 & $0.124 \pm 0.111$ \\
\hline$\sum 8 \mathrm{PAHs}$ & $0.90 \pm 0.57$ & 0.283 & 0.322 & 47 & $0.604 \pm 0.477$ & 0.368 & 0.818 & 31 & $1.19 \pm 0.87$ \\
\hline HCB & $0.053 \pm 0.021$ & 0.055 & $<L O Q$ & 100 & $0.055 \pm 0.005$ & 0.033 & $<L O Q$ & 100 & $0.033 \pm 0.007$ \\
\hline $\mathrm{PeCB}$ & $0.016 \pm 0.0038$ & 0.014 & $<L O Q$ & 100 & $0.014 \pm 0.001$ & 0.017 & $<L O Q$ & 100 & $0.018 \pm 0.001$ \\
\hline CB52 & $0.022 \pm 0.010$ & 0.029 & $<L O Q$ & 100 & $0.029 \pm 0.007$ & 0.014 & $<L O Q$ & 100 & $0.014 \pm 0.008$ \\
\hline CB153 & $0.006 \pm 0.003$ & 0.007 & 0.0002 & 98 & $0.008 \pm 0.001$ & 0.003 & 0.0007 & 75 & $0.004 \pm 0.001$ \\
\hline$\sum \mathrm{PCBi}$ & $0.059 \pm 0.026$ & 0.077 & 0.001 & 99 & $0.079 \pm 0.017$ & 0.034 & 0.005 & 87 & $0.039 \pm 0.015$ \\
\hline$\sum$ PCB-DL & $0.006 \pm 0.003$ & 0.008 & 0.001 & 93 & $0.009 \pm 0.001$ & 0.004 & 0.0002 & 95 & $0.004 \pm 0.002$ \\
\hline DEP & $3.78 \pm 1.81$ & 5.99 & 0.436 & 99 & $6.03 \pm 1.09$ & 2.52 & 0.50 & 83 & $3.02 \pm 0.48$ \\
\hline DiBP & $3.56 \pm 2.39$ & 6.42 & 0.330 & 97 & $6.60 \pm 0.99$ & 2.29 & 0.255 & 90 & $2.54 \pm 0.97$ \\
\hline DnBP & $1.20 \pm 1.10$ & 2.45 & 0.156 & 95 & $2.57 \pm 0.96$ & 0.742 & $<L O Q$ & 100 & $0.742 \pm 0.446$ \\
\hline DEHP & $12.8 \pm 15.7$ & 21.3 & 1.20 & 95 & $22.5 \pm 17.9$ & 1.41 & 1.75 & 45 & $3.16 \pm 3.7$ \\
\hline ¿7Phthalates & $24.1 \pm 20.4$ & 37.7 & 1.57 & 96 & $39.3 \pm 18.6$ & 7.16 & 1.81 & 80 & $8.97 \pm 0.47$ \\
\hline BDE47 & $0.001 \pm 0.0003$ & 0.001 & 0.0005 & 92 & 0.001 & 0.0002 & 0.00055 & 30 & $0.0008 \pm 0.0003$ \\
\hline BDE209 & & $<L O Q$ & $\angle L O Q$ & & & $<L O Q$ & $<L O Q$ & - & \\
\hline ¿8PBDEs & $0.0014 \pm 0.0006$ & 0.0011 & 0.0006 & 82 & 0.001 & 0.0004 & 0.0013 & 22 & $0.002 \pm 0.002$ \\
\hline
\end{tabular}

Winter 2011-2012 (n=3)

Summer $2011(\mathrm{n}=3)$

$733<L O Q$ : below the limit of quantification

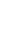


Table 2: Concentrations of different EDCs as annual concentrations in total air (mean \pm SD), as seasonal concentrations in the gaseous, the particulate phases and the total air $\left(\mathrm{ng} \mathrm{m}^{-3}\right)$ and as gaseous (\% of total air) at Paris and at Fontainebleau, during summer 2010 and winter $737 \quad 2010-2011$.

\begin{tabular}{|c|c|c|c|c|c|c|c|c|c|}
\hline \multirow{3}{*}{ compound } & \multirow{2}{*}{$\begin{array}{c}\text { Annual } \\
\text { concentration }(\mathrm{n}=6) \\
\text { Total } \\
\left(\mathrm{ng} \mathrm{m}^{-3}\right)\end{array}$} & \multirow[b]{2}{*}{$\begin{array}{l}\text { Gaseous } \\
\left(\mathrm{ng} \mathrm{m}^{-3}\right)\end{array}$} & \multicolumn{2}{|c|}{$\begin{array}{c}\text { Summer } 2010 \\
(\mathrm{n}=3)\end{array}$} & \multicolumn{5}{|c|}{$\begin{array}{c}\text { Winter 2010-2011 } \\
(\mathrm{n}=3)\end{array}$} \\
\hline & & & $\begin{array}{l}\text { Particulate } \\
\left(\mathrm{ng} \mathrm{m}^{-3}\right)\end{array}$ & $\begin{array}{l}\text { Gaseous } \\
(\%)\end{array}$ & $\begin{array}{l}\text { Total } \\
\left(\mathrm{ng} \mathrm{m}^{-3}\right)\end{array}$ & $\begin{array}{l}\text { Gaseous } \\
\left(\mathrm{ng} / \mathrm{m}^{3}\right)\end{array}$ & $\begin{array}{l}\text { Particulate } \\
\left(\mathrm{ng} \mathrm{m}^{-3}\right)\end{array}$ & $\begin{array}{l}\text { Gaseous } \\
(\%)\end{array}$ & $\begin{array}{c}\text { Total } \\
\left(\mathrm{ng} \mathrm{m}^{-3}\right)\end{array}$ \\
\hline & \multicolumn{9}{|c|}{ Paris } \\
\hline $\mathrm{OP}$ & $0.38 \pm 0.38$ & 0.625 & 0.032 & 95 & $0.657 \pm 0.379$ & 0.094 & 0.014 & 87 & $0.11 \pm 0.024$ \\
\hline NP & $1.14 \pm 0.45$ & 1.98 & 0.099 & 95 & $2.08 \pm 1.15$ & 0.392 & 0.094 & 81 & $0.49 \pm 0.21$ \\
\hline$\sum \mathrm{OP}+\mathrm{NP}$ & $1.66 \pm 1.49$ & 2.60 & 0.131 & 95 & $2.74 \pm 1.44$ & 0.49 & 0.11 & 82 & $0.59 \pm 0.23$ \\
\hline $\mathrm{BPA}$ & $0.048 \pm 0.053$ & 0.073 & 0.017 & 81 & $0.089 \pm 0.047$ & 0.011 & $<L O Q$ & 100 & 0.011 \\
\hline TBBPA & & $<L O Q$ & $<L O Q$ & & & $<L O Q$ & $<L O Q$ & & \\
\hline FLU & $1.8 \pm 0.7$ & 1.72 & $<L O Q$ & 100 & $1.72 \pm 0.79$ & 1.88 & $<L O Q$ & 100 & $1.88 \pm 4.08$ \\
\hline PHE & $5.4 \pm 1.2$ & 5.01 & 0.003 & 99 & $5.01 \pm 1.02$ & 5.76 & 0.089 & 98 & $5.85 \pm 1.46$ \\
\hline $\mathrm{BaP}$ & $0.07 \pm 0.07$ & 0.005 & 0.018 & 23 & $0.023 \pm 0.009$ & 0.019 & 0.102 & 16 & $0.121 \pm 0.083$ \\
\hline$\sum 8 \mathrm{PAHs}$ & $1.4 \pm 0.7$ & 0.897 & 0.051 & 95 & $0.948 \pm 0.304$ & 1.22 & 0.71 & 63 & $1.93 \pm 0.62$ \\
\hline HCB & $0.054 \pm 0.022$ & 0.066 & 0.001 & 99 & $0.067 \pm 0.027$ & 0.042 & $<L O Q$ & 100 & $0.042 \pm 0.009$ \\
\hline $\mathrm{PeCB}$ & $0.017 \pm 0.005$ & 0.015 & $<L O Q$ & 97 & $0.016 \pm 0.008$ & 0.019 & $<L O Q$ & 100 & $0.019 \pm 0.002$ \\
\hline CB52 & $0.065 \pm 0.047$ & 0.091 & 0.012 & 88 & $0.103 \pm 0.033$ & 0.027 & 0.002 & 96 & $0.029 \pm 0.016$ \\
\hline CB153 & $0.023 \pm 0.007$ & 0.026 & 0.018 & 59 & $0.044 \pm 0.023$ & 0.023 & 0.007 & 77 & $0.03 \pm 0.02$ \\
\hline$\sum \mathrm{PCBi}$ & $0.19 \pm 0.16$ & 0.267 & 0.060 & 82 & $0.327 \pm 0.091$ & 0.055 & 0.002 & 96 & $0.057 \pm 0.033$ \\
\hline$\sum$ PCB-DL & $0.020 \pm 0.025$ & 0.032 & 0.002 & 94 & $0.034 \pm 0.032$ & 0.006 & 0.001 & 87 & $0.007 \pm 0.004$ \\
\hline DEP & $1.85 \pm 2.32$ & 3.67 & $<L O Q$ & 100 & $3.67 \pm 1.90$ & $<L O Q$ & $<L O Q$ & & $<L O Q$ \\
\hline DiBP & $15.0 \pm 11.9$ & 24.7 & 0.211 & 99 & $24.9 \pm 7.17$ & 5.05 & 0.128 & 82 & $5.19 \pm 4.17$ \\
\hline DnBP & $4.49 \pm 5.08$ & 8.3 & $<L O Q$ & 100 & $8.31 \pm 4.54$ & 0.671 & $<L O Q$ & 100 & $0.671 \pm 0.523$ \\
\hline DEHP & $60.3 \pm 71.3$ & 58.7 & 3.8 & 93 & $62.6 \pm 75.8$ & 1.8 & 7.7 & 19 & $9.5 \pm 4.4$ \\
\hline$\sum 7$ Phthalates & $83.3 \pm 91.0$ & 151 & 14.9 & 90 & $165 \pm 91.6$ & 7.55 & 8.1 & 48 & $15.7 \pm 9.2$ \\
\hline BDE47 & 0.001 & 0.001 & $<L O Q$ & 100 & & $<L O Q$ & $<L O Q$ & 64 & $0.02 \pm 0.01$ \\
\hline BDE209 & $0.007 \pm 0.003$ & 0.007 & 0.002 & 75 & $0.009 \pm 0.004$ & 0.004 & 0.002 & 70 & $0.006 \pm 0.001$ \\
\hline \multirow[t]{2}{*}{$\sum 8 \mathrm{PBDEs}$} & $0.0098 \pm 0.0011$ & 0.013 & 0.002 & 85 & $0.016 \pm 0.003$ & 0.004 & 0.001 & 88 & $0.005 \pm 0.001$ \\
\hline & \multicolumn{9}{|c|}{ Fontainebleau } \\
\hline $\mathrm{OP}$ & $0.15 \pm 0.14$ & 0.238 & 0.029 & 89 & $0.267 \pm 0.087$ & 0.033 & 0.004 & 88 & $0.037 \pm 0.023$ \\
\hline NP & $0.45 \pm 0.27$ & 0.626 & 0.065 & 91 & $0.691 \pm 0.03$ & 0.162 & 0.054 & 75 & $0.216 \pm 0.157$ \\
\hline$\sum \mathrm{OP}+\mathrm{NP}$ & $0.60 \pm 0.41$ & 0.864 & 0.094 & 90 & $0.957 \pm 0.109$ & 0.195 & 0.058 & 77 & $0.253 \pm 0.179$ \\
\hline BPA & 0.116 & 0.116 & $<L O Q$ & 100 & 0.116 & 0.015 & $<L O Q$ & 100 & 0.015 \\
\hline TBBPA & & $<L O Q$ & $<L O Q$ & & & $<L O Q$ & $<L O Q$ & & \\
\hline FLU & $1.3 \pm 0.42$ & 1.22 & $<L O Q$ & 100 & $1.22 \pm 0.51$ & 1.41 & $<L O Q$ & 100 & $1.41 \pm 0.39$ \\
\hline PHE & $2.6 \pm 1.2$ & 1.65 & $<L O Q$ & 100 & $1.65 \pm 0.44$ & 3.432 & 0.050 & 99 & $3.48 \pm 1.02$ \\
\hline $\mathrm{BaP}$ & $0.050 \pm 0.037$ & 0.004 & 0.005 & 48 & $0.009 \pm 0.008$ & $<\mathrm{LOQ}$ & 0.073 & 0 & $0.073 \pm 0.026$ \\
\hline$\sum 8 \mathrm{PAHs}$ & $0.70 \pm 0.57$ & 0.200 & 0.015 & 93 & $0.215 \pm 0.024$ & 0.646 & 0.531 & 55 & $1.18 \pm 0.33$ \\
\hline HCB & $0.048 \pm 0.015$ & 0.053 & 0.001 & 99 & $0.054 \pm 0.014$ & 0.042 & $<L O Q$ & 100 & $0.042 \pm 0.016$ \\
\hline $\mathrm{PeCB}$ & $0.015 \pm 0.006$ & 0.012 & $<L O Q$ & 98 & $0.013 \pm 0.007$ & 0.018 & $<L O Q$ & 100 & $0.018 \pm 0.006$ \\
\hline CB52 & $0.026 \pm 0.023$ & 0.053 & 0.009 & 85 & $0.062 \pm 0.009$ & 0.019 & 0.002 & 89 & $0.021 \pm 0.017$ \\
\hline CB153 & $0.017 \pm 0.012$ & 0.010 & 0.013 & 43 & $0.023 \pm 0.008$ & 0.009 & 0.002 & 86 & $0.011 \pm 0.005$ \\
\hline$\sum \mathrm{PCBi}$ & $0.10 \pm 0.09$ & 0.134 & 0.045 & 75 & $0.180 \pm 0.031$ & 0.021 & 0.004 & 85 & $0.024 \pm 0.013$ \\
\hline$\sum \overline{\mathrm{PCB}}-\mathrm{DL}$ & $0.0068 \pm 0.0059$ & 0.007 & 0.004 & 62 & $0.012 \pm 0.004$ & 0.001 & 0.001 & 70 & $0.002 \pm 0.002$ \\
\hline DEP & $0.78 \pm 0.92$ & 1.51 & $<L O Q$ & 100 & $1.51 \pm 0.721$ & $<L O Q$ & $<L O Q$ & & \\
\hline DiBP & $4.02 \pm 2.50$ & 5.83 & $<L O Q$ & 100 & $5.83 \pm 2.30$ & 1.53 & 0.695 & 60 & $2.21 \pm 0.80$ \\
\hline DnBP & $1.20 \pm 1.07$ & 1.99 & $<L O Q$ & 100 & $1.99 \pm 0.99$ & 0.367 & 0.061 & 94 & $0.416 \pm 0.273$ \\
\hline DEHP & $10.9 \pm 14.4$ & 17.8 & $<L O Q$ & 100 & $17.8 \pm 19.3$ & 1.32 & 2.72 & 33 & $4.0 \pm 2.5$ \\
\hline$\sum 7$ Phthalates & $17.3 \pm 18.3$ & 27.7 & 0.02 & 99.7 & $27.9 \pm 22.4$ & 3.24 & 3.56 & 48 & $6.8 \pm 2.8$ \\
\hline BDE47 & $0.0006 \pm 0.0005$ & 0.001 & $<L O Q$ & 100 & $0.001 \pm 0.001$ & 0.000 & $<L O Q$ & 84 & $<L O Q$ \\
\hline BDE209 & $0.0088 \pm 0.0048$ & 0.006 & 0.003 & 66 & $0.010 \pm 0.004$ & 0.007 & 0.001 & 90 & $0.008 \pm 0.006$ \\
\hline$\sum 8$ PBDEs & $0.0103 \pm 0.0065$ & 0.009 & 0.004 & 70 & $0.012 \pm 0.004$ & 0.007 & $<L O Q$ & 98 & $0.008 \pm 0.006$ \\
\hline
\end{tabular}


740 Table 3: Spearman'r coefficient between air temperature, PM10 and EDC ambient air

741 concentrations at Paris (bold: significant $r$ values for $\mathrm{p}<0.05, \mathrm{n}=14$ ).

\begin{tabular}{|c|c|c|c|c|c|c|c|c|c|c|c|c|c|c|}
\hline & $\mathrm{T}^{\circ} \mathrm{C}$ & PM10 & CB52 & CB153 & $\mathrm{HCB}$ & $\mathrm{PeCB}$ & DEP & DEHP & BDE47 & BDE100 & FLU & $\mathrm{BaP}$ & OP & NP \\
\hline PM10 & -0.585 & 1 & & & & & & & & & & & & \\
\hline CB52 & 0.720 & -0.472 & 1 & & & & & & & & & & & \\
\hline CB153 & 0.832 & -0.574 & 0.832 & 1 & & & & & & & & & & \\
\hline HCB & 0.692 & -0.373 & 0.462 & 0.573 & 1 & & & & & & & & & \\
\hline PeCB & 0.070 & 0.278 & -0.294 & -0.196 & 0.259 & 1 & & & & & & & & \\
\hline DEP & 0.606 & -0.691 & 0.613 & 0.620 & 0.577 & -0.437 & 1 & & & & & & & \\
\hline DEHP & 0.538 & -0.521 & 0.636 & 0.832 & 0.315 & -0.538 & 0.472 & 1 & & & & & & \\
\hline BDE47 & -0.182 & 0.028 & 0.238 & 0.126 & -0.259 & 0.084 & -0.282 & 0.091 & 1 & & & & & \\
\hline BDE100 & 0.049 & -0.201 & 0.594 & 0.413 & -0.112 & -0.378 & 0.077 & 0.434 & 0.573 & 1 & & & & \\
\hline FLU & -0.154 & 0.225 & -0.364 & -0.280 & -0.147 & 0.329 & -0.148 & -0.336 & -0.252 & -0.420 & 1 & & & \\
\hline $\mathrm{BaP}$ & -0.825 & 0.803 & -0.490 & -0.706 & -0.517 & 0.105 & -0.577 & -0.587 & 0.091 & 0.028 & 0.350 & 1 & & \\
\hline $\mathrm{OP}$ & 0.839 & -0.592 & 0.762 & 0.762 & 0.629 & -0.252 & 0.859 & 0.531 & -0.357 & 0.091 & -0.042 & -0.615 & 1 & \\
\hline NP & 0.266 & 0.067 & 0.434 & 0.469 & 0.322 & 0.049 & 0.225 & 0.259 & -0.077 & 0.350 & 0.133 & 0.126 & 0.469 & 1 \\
\hline
\end{tabular}




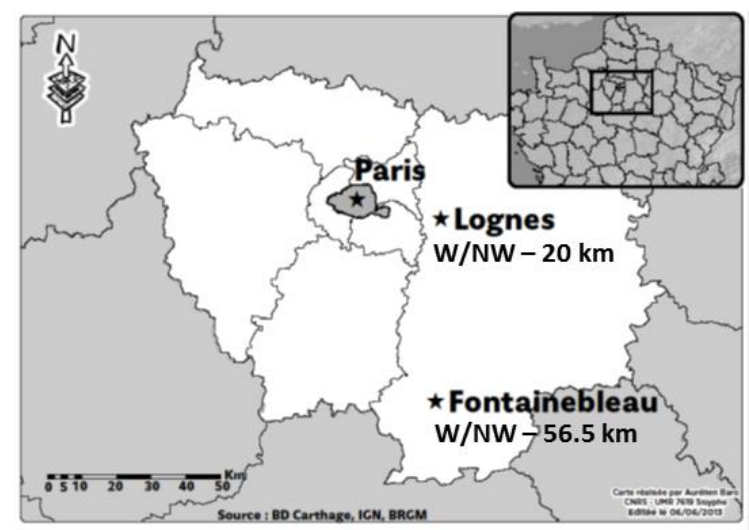

744 Fig. SM.1: Location of the sampling sites of Airparif (1: urban site - Paris 13th; 2: suburban site - Lognes; 3: forest site - Fontainebleau), 745 prevailing wind direction and distance from the urban site. 
747 Table SM.1: Sampling conditions for two campaigns at the urban (Paris), the suburban (Lognes) and the forest (Fontainebleau) sites.

\begin{tabular}{|c|c|c|c|c|c|c|c|c|c|}
\hline Season & $\begin{array}{l}\text { Sunshine } \\
\text { duration } \\
\text { (hours) }\end{array}$ & Period & Sites & $\begin{array}{l}\text { Ozone } \\
\mu \mathrm{g} \mathrm{m}^{-3}\end{array}$ & $\begin{array}{c}\text { Air sample } \\
\text { volume } \\
\left(\mathrm{m}^{3}\right)\left(\begin{array}{l}(\text { mean } \pm \mathrm{SD}) \\
\text { (n) }\end{array}\right.\end{array}$ & $\begin{array}{c}\text { Air flow } \\
\left(\mathrm{m}^{3} \mathrm{~h}^{-1}\right) \\
(\mathrm{mean} \pm \mathrm{SD})\end{array}$ & $\begin{array}{c}\text { Air } \\
\text { temperature } \\
\left({ }^{\circ} \mathrm{C}\right)\end{array}$ & $\begin{array}{c}\text { PM10 } \\
\text { concentrations } \\
\text { Airparif }\left(\mu \mathrm{g} \mathrm{m}^{-3}\right)\end{array}$ & $\begin{array}{l}\text { Cumulative } \\
\text { precipitation } \\
(\mathrm{mm})\end{array}$ \\
\hline \multirow[b]{2}{*}{ Summer 2010} & \multirow[b]{2}{*}{195} & $06 / 01-06 / 16 / 10$ & Paris & $65.7 \pm 36.9$ & $276 \pm 135$ & $1.4 \pm 0.3$ & $20.9 \pm 3.1$ & $22.2 \pm 3.2$ & 90.3 \\
\hline & & $\begin{array}{l}06 / 16-06 / 30 / 10 \\
06 / 30-07 / 13 / 10\end{array}$ & Fontainebleau & $70.4 \pm 34.4$ & $357 \pm 13$ & $1.3 \pm 0.1$ & $19.2 \pm 2.7$ & $18.0 \pm 0.9$ & 95.6 \\
\hline \multirow[b]{2}{*}{ Winter 2010/2011 } & \multirow[b]{2}{*}{36} & $01 / 06-01 / 20 / 11$ & Paris & $23.5 \pm 17.9$ & $331 \pm 79$ & $1.2 \pm 0.3$ & $6.3 \pm 3.4$ & $28.7 \pm 9.6$ & 43.4 \\
\hline & & $\begin{array}{l}01 / 20-02 / 02 / 11 \\
02 / 02-02 / 16 / 11\end{array}$ & Fontainebleau & $44.8 \pm 18.7$ & $401 \pm 7$ & $1.4 \pm 0.1$ & $4.7 \pm 3.3$ & $24.5 \pm 9.2$ & 50.4 \\
\hline \multirow[b]{2}{*}{ Summer 2011} & \multirow[b]{2}{*}{158} & $05 / 30-06 / 14 / 11$ & Paris & $57.9 \pm 29.5$ & $499 \pm 82$ & $1.7 \pm 0.2$ & $19.2 \pm 1.0$ & $19.3 \pm 2.3$ & 86.2 \\
\hline & & $\begin{array}{l}06 / 14-06 / 28 / 11 \\
06 / 28-07 / 12 / 11\end{array}$ & Lognes & $61.8 \pm 32.5$ & $555 \pm 59$ & $1.9 \pm 0.1$ & $18.4 \pm 1.0$ & $16.8 \pm 1.7$ & 98.9 \\
\hline \multirow{2}{*}{ Winter 2011/2012 } & \multirow{2}{*}{107} & $01 / 24-02 / 08 / 12$ & Paris & $19.8 \pm 16.5$ & $454 \pm 38$ & $1.5 \pm 0.1$ & $4.0 \pm 4.1$ & $37.9 \pm 4.8$ & 19.4 \\
\hline & & $\begin{array}{l}02 / 08-02 / 21 / 12 \\
02 / 21-03 / 06 / 12\end{array}$ & Lognes & $24.7 \pm 18.5$ & $475 \pm 98$ & $1.6 \pm 0.2$ & $3.0 \pm 4.3$ & $32.7 \pm 1.8$ & 27.4 \\
\hline
\end{tabular}


Table SM.2: Specifications for the GC analyses

\begin{tabular}{|c|c|c|c|c|c|c|}
\hline Compound & Chromatography & Apparatus & Injector & Column & Oven parameters & Vector gas \\
\hline PAHs & GCMS-EI & $\begin{array}{l}\text { Agilent GC } \\
(7890)-M S \\
(5975)\end{array}$ & $\begin{array}{l}\text { pulsed Splitless } \\
280^{\circ} \mathrm{C} ; 1 \mu \mathrm{L}\end{array}$ & $\begin{array}{c}\text { ZB-5MS }(30 \mathrm{~m}, 250 \mu \mathrm{m} \mathrm{ID}, 0.25 \mu \mathrm{m} \text { film thickness from } \\
\text { Phenomenex) with a deactivated silica pre-column ( } 1 \mathrm{~m} \text {; } \\
0.25 \mathrm{~mm} \text { ID from Restek) }\end{array}$ & $\begin{array}{l}90^{\circ} \mathrm{C} \text { for } 1 \mathrm{~min} \text {, then } 10^{\circ} \mathrm{C} / \mathrm{min} \text { to } 160^{\circ} \mathrm{C} \text { for } 0 \mathrm{~min}, 5^{\circ} \mathrm{C} / \mathrm{min} \text { to } \\
240^{\circ} \mathrm{C} \text { for } 10 \mathrm{~min} \text { and } 4^{\circ} \mathrm{C} / \mathrm{min} \text { to } 300^{\circ} \mathrm{C} \text { for } 2 \mathrm{~min}\end{array}$ & $\begin{array}{l}\text { Helium } \\
1 \mathrm{~mL} / \mathrm{min}\end{array}$ \\
\hline $\begin{array}{l}\text { PCBs } \\
\text { HCB } \\
\text { PeCB }\end{array}$ & GCMSMS-EI & $\begin{array}{l}\text { GC (7890) triple } \\
\text { Quad (7000A) }\end{array}$ & $\begin{array}{l}\text { pulsed Splitless } \\
280^{\circ} \mathrm{C} ; 1 \mu \mathrm{L}\end{array}$ & $\begin{array}{c}\text { HT8 }(50 \mathrm{~m}, 250 \mu \mathrm{m} \text { ID, } 0.25 \mu \mathrm{m} \text {; from SGE) with a } \\
\text { deactivated silica pre-column }(1 \mathrm{~m} ; 0 ., 25 \mathrm{~mm} \text { ID from } \\
\text { Restek })\end{array}$ & $\begin{array}{l}80^{\circ} \mathrm{C} \text { for } 2 \mathrm{~min} \text {, then } 30^{\circ} \mathrm{C} / \mathrm{min} \text { to } 170{ }^{\circ} \mathrm{C} \text { for } 0 \mathrm{~min} \text { and } 3{ }^{\circ} \mathrm{C} / \mathrm{min} \\
\text { to } 300^{\circ} \mathrm{C} \text { for } 3 \mathrm{~min}\end{array}$ & $\underset{\text { psi }}{\text { Helium }} 40$ \\
\hline PAEs & GCMS-EI & $\begin{array}{l}\text { Agilent GC } \\
\text { (7890)-MS } \\
(5975)\end{array}$ & $\begin{array}{l}\text { splitless } 290^{\circ} \mathrm{C} \\
\quad 1 \mu \mathrm{L}\end{array}$ & $\begin{array}{c}\text { ZB-5MS }(30 \mathrm{~m}, 250 \mu \mathrm{m} \mathrm{ID}, 0.25 \mu \mathrm{m} \text { film thickness from } \\
\text { Phenomenex) with a deactivated silica pre-column ( } 1 \mathrm{~m} \text {; } \\
0.25 \mathrm{~mm} \text { ID) }\end{array}$ & $\begin{array}{l}50^{\circ} \mathrm{C} \text { for } 1 \mathrm{~min} \text {, then } 30^{\circ} \mathrm{C} / \mathrm{min} \text { to } 280^{\circ} \mathrm{C} \text { and } 15^{\circ} \mathrm{C} / \mathrm{min} \text { to } 310^{\circ} \mathrm{C} \\
\text { for } 4 \mathrm{~min}\end{array}$ & $\begin{array}{l}\text { Helium } \\
1 \mathrm{~mL} / \mathrm{min}\end{array}$ \\
\hline PBDEs & GCMSMS-EI & $\begin{array}{l}\text { GC (7890) triple } \\
\text { Quad (7000A) }\end{array}$ & $\begin{array}{l}\text { pulsed Splitless } \\
285^{\circ} \mathrm{C} ; 1 \mu \mathrm{L}\end{array}$ & $\begin{array}{l}\text { J\&W HP-5MS analytical column }(15 \mathrm{~m}, 250 \mu \mathrm{m} \text { ID, } 0.25 \\
\mu \mathrm{m} \text { film thickness) with a deactivated silica pre-column (1 } \\
\mathrm{m} ; 0.25 \mathrm{~mm} \text { ID) }\end{array}$ & $\begin{array}{l}102{ }^{\circ} \mathrm{C} \text { for } 0.8 \mathrm{~min} \text {, then } 25^{\circ} \mathrm{C} / \mathrm{min} \text { to } 185^{\circ} \mathrm{C} \text { for } 0 \mathrm{~min}, 15^{\circ} \mathrm{C} / \mathrm{min} \\
\text { to } 2700^{\circ} \mathrm{C} \text { for } 0 \mathrm{~min}, 5^{\circ} \mathrm{C} / \mathrm{min} \text { to } 285^{\circ} \mathrm{C} \text { for } 0 \text { min and } 30^{\circ} \mathrm{C} / \mathrm{min} \text { to } \\
315^{\circ} \mathrm{C} \text { for } 3.1 \mathrm{~min}\end{array}$ & $\begin{array}{c}\text { Helium } 1.8 \\
\mathrm{~mL} / \mathrm{min}\end{array}$ \\
\hline
\end{tabular}


Table SM.3: Specifications for the LC-MS/MS analyses

\begin{tabular}{|c|c|c|c|c|c|c|c|c|c|c|c|}
\hline Compound & \multicolumn{2}{|c|}{ Chromatography } & \multirow{3}{*}{$\begin{array}{c}\text { Apparatus } \\
\text { Agilent LC (SL serie } \\
\text { 1200) triple Quad } \\
\text { (G6410 BA) } \\
\text { AQUITY } \\
\text { UPLC@/TQD } \\
\text { (Waters). } \\
\end{array}$} & Injector & \multirow{3}{*}{$\begin{array}{c}\text { Column } \\
\text { Zorbax Eclipse XDB-C18 } \\
\text { (4.6 X } 50 \mathrm{~mm} ; 1.8 \mu \mathrm{m} ; \\
\text { Agilent). Chauffée à } 50^{\circ} \mathrm{C} \text {. } \\
\text { AQUITY UPLC/BEH C18 } \\
\text { (2.1 mm X } 100 \mathrm{~mm} ; 1.7 \mu \mathrm{m} \text {; } \\
\text { Water). Chauffée à } 40^{\circ} \mathrm{C} \text {. }\end{array}$} & \multicolumn{5}{|c|}{ Mobile phase } & Flow \\
\hline $\begin{array}{c}\text { BAP } \\
\text { TBBPA }\end{array}$ & \multicolumn{2}{|c|}{ LCMSMS-ESI } & & Standard: $10 \mu \mathrm{L}$ & & \multicolumn{5}{|c|}{$\begin{array}{l}\text { Methanol/water Gradient: } 40 / 60 \text { at } 0 \mathrm{~min} \text { then } 100 / 0 \text { from } 0 \text { to } 10 \mathrm{~min} \text {, } \\
100 / 0 \text { from } 10 \text { to } 12 \mathrm{~min} \text { and } 40 / 60 \text { from } 12 \text { to } 17 \mathrm{~min} .\end{array}$} & $\begin{array}{c}0.5 \\
\mathrm{~mL} / \mathrm{min}\end{array}$ \\
\hline Alkylphenols & \multicolumn{2}{|c|}{ LCMSMS-ESI } & & Standard: $10 \mu \mathrm{L}$ & & \multicolumn{5}{|c|}{$\begin{array}{l}\text { Methanol and water with ammonium hydroxyde } 0,05 \% \text { Gradient:50/50 at } 0 \\
\text { min then } 95 / 5 \text { from } 0 \text { to } 3 \text { min, 100/0 from } 3 \text { to } 5 \text { min and } 50 / 50 \text { from } 5 \text { to } 8 \\
\text { min. }\end{array}$} & $\begin{array}{c}0.4 \\
\mathrm{~mL} / \mathrm{min}\end{array}$ \\
\hline \multirow[t]{2}{*}{ EDs } & Compounds & Internal standard & $\mathrm{RT}(\min )$ & Source & $\mathrm{m} / \mathrm{z}$ precursor ion & Fragmentor (V) & \multicolumn{2}{|c|}{$\mathrm{m} / \mathrm{z}$ quantification } & \multicolumn{2}{|c|}{$\mathrm{m} / \mathrm{z}$ qualification } & Collision \\
\hline & & & & & & & ion fils & $\mathrm{Ce}(\mathrm{eV})$ & ion fils & $\mathrm{Ce}(\mathrm{eV})$ & \\
\hline \multirow[b]{2}{*}{ Alkylphenols } & $\mathrm{OP}$ & $\mathrm{n}-\mathrm{NP}$ & 3.25 & ESI negatif ; $\mathrm{N}_{2}$ : & 205 & 45 & 134.2 & 17 & 133.2 & 30 & \multirow[b]{2}{*}{$\begin{array}{l}\operatorname{Ar}(0.25 \\
\mathrm{mL} / \mathrm{min})\end{array}$} \\
\hline & NP & $\mathrm{n}-\mathrm{NP}$ & 3.52 & $\begin{array}{l}380^{\circ} \mathrm{C} \text {; gas flow: } \\
800 \mathrm{~L} / \mathrm{h} \text {; Capillaire: } \\
2800 \mathrm{~V}\end{array}$ & 219 & 40 & 133.2 & 26 & 147.2 & 26 & \\
\hline \multirow{4}{*}{ Phenols } & BPA & $\begin{array}{c}\text { BPA-d16 } \\
13\end{array}$ & 5.35 & ESI negatif ; $\mathrm{N}_{2}$ : & 227.1 & 125 & 212.1 & 12 & 133.1 & 20 & \multirow{4}{*}{$\mathrm{N}_{2}$} \\
\hline & $\begin{array}{l}\text { TBBPA } \\
\text { Ethyl-P }\end{array}$ & ${ }^{13} \mathrm{C}_{12}$-TBBPA & 9.3 & $350^{\circ} \mathrm{C}$; gas flow: & $\begin{array}{c}543 \\
1651\end{array}$ & 130 & 81 & 60 & 417.8 & 40 & \\
\hline & $\begin{array}{l}\text { Enyli- } \\
\text { Propyl-P }\end{array}$ & & $\begin{array}{l}4.1 \\
5.4\end{array}$ & $660 \mathrm{~L} / \mathrm{h}$; Capillaire: & 165.1 & 110 & 92 & 20 & 137 & 8 & \\
\hline & Butyl-P & & 6.5 & $4000 \mathrm{~V}$ & $\begin{array}{l}179.1 \\
193.1\end{array}$ & $\begin{array}{c}80 \\
110\end{array}$ & $\begin{array}{l}92 \\
92\end{array}$ & $\begin{array}{l}24 \\
20\end{array}$ & $\begin{array}{l}136 \\
136\end{array}$ & $\begin{array}{l}12 \\
12\end{array}$ & \\
\hline
\end{tabular}

RT: Retention Time; Ce: Collision energy; ESI: Electro Spray Ionization 

transition for qualification).

\begin{tabular}{|c|c|c|c|c|c|c|c|}
\hline Family & Compounds & Internal standard & $\mathrm{m} / \mathrm{z}$ precursor & $\mathrm{m} / \mathrm{z}$ product & Dwell Time (ms) & $\mathrm{Ec}$ & Others \\
\hline \multirow{16}{*}{ PCBs } & $\mathrm{PeCB}$ & $\mathrm{CB} 30$ & 250 & $215 \mathrm{Q}$ & 50 & 25 & \multirow{16}{*}{$\begin{array}{c}\text { Source: } 300{ }^{\circ} \mathrm{C} \\
\text { Interface: } 250{ }^{\circ} \mathrm{C} \\
\text { Quadrupoles: } 150^{\circ} \mathrm{C}\end{array}$} \\
\hline & & & 250 & $142 \mathrm{q}$ & 50 & 40 & \\
\hline & $\mathrm{HCB}$ & CB30 & 249 & $214 \mathrm{Q}$ & 50 & 13 & \\
\hline & & & 284 & $249 \mathrm{q}$ & 50 & 18 & \\
\hline & Tri & CB30 & 256 & $186 \mathrm{Q}$ & 50 & 25 & \\
\hline & & & 256 & $151 \mathrm{q}$ & 50 & 25 & \\
\hline & Tetra & CB30 & 292 & $222 \mathrm{Q}$ & 25 & 27 & \\
\hline & \multirow{3}{*}{ Penta } & \multirow{3}{*}{ CB107 } & 292 & $220 \mathrm{q}$ & 25 & 27 & \\
\hline & & & 326 & $256 \mathrm{Q}$ & 25 & 27 & \\
\hline & & & 326 & $254 \mathrm{q}$ & 25 & 27 & \\
\hline & \multirow[t]{2}{*}{ Hexa } & \multirow[t]{2}{*}{ CB107 } & 360 & $290 \mathrm{Q}$ & 25 & 27 & \\
\hline & & & 360 & $325 \mathrm{q}$ & 25 & 12 & \\
\hline & \multirow[t]{2}{*}{ Hepta } & \multirow[t]{2}{*}{ CB107 } & 394 & $324 \mathrm{Q}$ & 60 & 20 & \\
\hline & & & 394 & $359 \mathrm{q}$ & 60 & 20 & \\
\hline & \multirow[t]{2}{*}{ 13C12 РCВ 194} & \multirow[t]{2}{*}{ Syringe standard } & 442 & $370 \mathrm{Q}$ & 60 & 40 & \\
\hline & & & 440 & $370 \mathrm{q}$ & 60 & 40 & \\
\hline \multirow{28}{*}{ PBDEs } & \multirow[t]{2}{*}{ BDE28 } & \multirow[t]{2}{*}{ 13C BDE47 } & 407.8 & $247.9 \mathrm{Q}$ & 90 & 20 & \\
\hline & & & 247.9 & $139 \mathrm{q}$ & 90 & 30 & \\
\hline & \multirow[t]{2}{*}{ BDE47 } & \multirow[t]{2}{*}{ 13C BDE47 } & 485.7 & $325.9 \mathrm{Q}$ & 80 & 25 & \\
\hline & & & 325.9 & $138 \mathrm{q}$ & 80 & 55 & \\
\hline & \multirow[t]{2}{*}{ BDE100 } & \multirow[t]{2}{*}{ 13C BDE47 } & 403.7 & $137 \mathrm{Q}$ & 75 & 55 & \\
\hline & & & 565.7 & $405.9 \mathrm{q}$ & 75 & 25 & \\
\hline & \multirow[t]{2}{*}{ BDE99 } & \multirow[t]{2}{*}{ 13C BDE47 } & 403.7 & $137 \mathrm{Q}$ & 75 & 55 & \\
\hline & & & 565.7 & $405.9 \mathrm{q}$ & 75 & 25 & \\
\hline & \multirow[t]{2}{*}{ BDE154 } & \multirow[t]{2}{*}{ 13C BDE153 } & 643.6 & $483.9 \mathrm{Q}$ & 75 & 25 & \\
\hline & & & 483.9 & $376.8 \mathrm{q}$ & 75 & 40 & \\
\hline & \multirow[t]{2}{*}{ BDE153 } & \multirow[t]{2}{*}{ 13C BDE153 } & 643.6 & $483.9 \mathrm{Q}$ & 75 & 25 & \\
\hline & & & 483.9 & $376.8 \mathrm{q}$ & 75 & 40 & \\
\hline & BDE183 & BDE181 & 561.6 & $454.6 \mathrm{Q}$ & 75 & 40 & Source: $275^{\circ} \mathrm{C}$ \\
\hline & & & 721.6 & $561.6 \mathrm{q}$ & 75 & 30 & \\
\hline & BDE209 & 13C BDE209 & 799.7 & $640 \mathrm{Q}$ & 75 & 55 & Interface: $250^{\circ} \mathrm{C}$ \\
\hline & & & 797.7 & $637.7 \mathrm{q}$ & 75 & 55 & Quadrupoles: $150{ }^{\circ} \mathrm{C}$ \\
\hline & 13C12 BDE47 & IS & 497.7 & $337.9 \mathrm{Q}$ & 80 & 25 & \\
\hline & & & 337.9 & $148.9 \mathrm{q}$ & 80 & 55 & \\
\hline & 13C12 BDE153 & IS & 655.7 & 495.8 Q & 75 & 25 & \\
\hline & & & 495.7 & $335.8 \mathrm{q}$ & 75 & 40 & \\
\hline & BDE181 & IS & 561.6 & $454.6 \mathrm{Q}$ & 75 & 40 & \\
\hline & & & 721.6 & $561.6 \mathrm{q}$ & 75 & 30 & \\
\hline & 13C12 BDE209 & IS & 811.4 & $651.4 \mathrm{Q}$ & 75 & 55 & \\
\hline & & & 809.4 & $649.5 \mathrm{q}$ & 75 & 55 & \\
\hline & BВ209 & IS & 943.5 & $783.7 \mathrm{Q}$ & 70 & 30 & \\
\hline & & & 783.7 & $625.7 \mathrm{q}$ & 70 & 45 & \\
\hline & CB209 & IS & 499.7 & $427.9 \mathrm{Q}$ & 75 & 30 & \\
\hline & & & 427.9 & $357.8 \mathrm{q}$ & 75 & 45 & \\
\hline
\end{tabular}


Table SM.5: Specifications for the GC/MS analysis.

\begin{tabular}{|c|c|c|c|c|}
\hline Compounds & Internal standards & $\mathrm{m} / \mathrm{z}$ ion quantification & $\mathrm{m} / \mathrm{z}$ ion qualification & Others \\
\hline Acenaphtylene & Phenanthrene d 10 & 152 & 151 & \multirow{8}{*}{ Source: $230^{\circ} \mathrm{C}$} \\
\hline Acenaphtene & Phenanthrene d10 & 153 & 154 & \\
\hline Fluorene & Phenanthrene d10 & 166 & 165 & \\
\hline Phenanthrene & Phenanthrene d10 & 178 & 179 & \\
\hline Anthracene & Phenanthrene d10 & 178 & 179 & \\
\hline Fluoranthene & Pyrene d10 & 202 & 200 & \\
\hline Pyrene & Pyrene d10 & 202 & 200 & \\
\hline Benzo(a)anthracene & Benzo(a)anthracene d12 & 228 & 226 & \\
\hline Chrysene & Benzo(a)anthracene d12 & 228 & 226 & \multirow{2}{*}{ Interface: $250{ }^{\circ} \mathrm{C}$} \\
\hline Benzo(b)fluoranthene & Benzo(a)anthracene d12 & 252 & 253 & \\
\hline Benzo(k)fluoranthene & Benzo(a)anthracene d12 & 252 & 253 & \multirow[t]{9}{*}{ Quadrupoles: $150^{\circ} \mathrm{C}$} \\
\hline Benzo(a)pyrene & Benzo(a)anthracene d12 & 252 & 253 & \\
\hline Indeno(1,2,3-cd)pyrene & Benzo(a)anthracene d12 & 276 & 274 & \\
\hline Dibenzo(a,h)anthracene & Benzo(a)anthracene d12 & 278 & 276 & \\
\hline Benzo(g,h,i)perylene & Benzo(a)anthracene d12 & 276 & 274 & \\
\hline Phenanthrene d10 & & 188 & 189 & \\
\hline Pyrene $\mathrm{d} 10$ & & 212 & 213 & \\
\hline Benzo(a)anthracene d12 & & 240 & 236 & \\
\hline Benzyl benzoate & Syringe standard & 105 & 212 & \\
\hline DMP & DPP & 163 & 194 & \multirow{5}{*}{ Source: $230{ }^{\circ} \mathrm{C}$} \\
\hline DEP & DPP & 149 & 177 & \\
\hline DiBP & DPP & 149 & 104 & \\
\hline DnBP & DPP & 149 & 223 & \\
\hline $\mathrm{BBP}$ & DPP & 149 & 104 & \\
\hline DEHP & DPP & 149 & 279 & Interface: $200{ }^{\circ} \mathrm{C}$ \\
\hline DnOP & DPP & 149 & 279 & \multirow{5}{*}{ Quadrupoles: $150^{\circ} \mathrm{C}$} \\
\hline DiNP & DPP & 293 & 149 & \\
\hline DiDP & DPP & 307 & 149 & \\
\hline DPP & & 149 & 104 & \\
\hline Benzyl benzoate & Syringe standard & 105 & 212 & \\
\hline
\end{tabular}


758 Table SM.6: Calibration ranges, correlations of the linear responses and quantities of native

759 compounds for the spiked matrices.

760

\begin{tabular}{cccc} 
Compounds & Calibration ranges $(\mathrm{pg})$ & $\mathrm{r}^{2}$ & Quantity $(\mathrm{ng})$ \\
\hline BPA & $2-20000$ & $>0.997$ & 50 \\
TBBPA & $2-20000$ & $>0.999$ & 50 \\
PAHs & $10-1000$ & $>0.996$ & 100 \\
HCB & $0.8-800$ & $>0.999$ & 100 \\
PeCB & $0.8-800$ & $>0.999$ & 100 \\
PCBs & $0.8-800$ & $>0.999$ & 50 \\
PAEs & $31.25-8000$ & $>0.998$ & 2000 \\
PBDEs & $35-476$ & $>0.999$ & 25 \\
BDE209 & $350-4760$ & $>0.998$ & 250
\end{tabular}


Table SM.7: Instrument detection limits (IDLs - pg on column for the low standard solutions, as the concentration with a signal/noise ratio of 3 peak to peak), limits of quantification (LOQs - $\mathrm{pg} \mathrm{m}^{-3}$ ), recoveries (as \% in spiked XAD-2 and filter matrices) and average blanks $\left(\mathrm{pg} \mathrm{m}^{-3}\right.$ ) for gaseous and particulate phases. For LOQs and recoveries, XAD-2 resin and quartz filters were spiked, before extraction, with all native compounds. After extraction, the ISs were added and the extract followed the entire procedure. The LOQ was

768 considered as the concentration (in $\mathrm{pg} \mathrm{m}^{-3}$ ) with a signal/noise ratio of 9 (peak to peak).

\begin{tabular}{|c|c|c|c|c|c|c|c|c|}
\hline Family & Compounds & $\begin{array}{c}\text { IDLs } \\
\text { (pg on column) }\end{array}$ & $\begin{array}{c}\text { LOQ } \\
\text { Gaseous } \\
\text { phase } \\
\end{array}$ & $\begin{array}{c}\text { LOQ } \\
\text { Particulate } \\
\text { phase }\end{array}$ & $\begin{array}{c}\text { Recovery } \\
\text { Gaseous } \\
\text { phase }\end{array}$ & $\begin{array}{c}\text { Recovery } \\
\text { Particulte } \\
\text { phase }\end{array}$ & $\begin{array}{c}\text { Average blanks } \\
\text { Gaseous phase } \\
\left(\mathrm{pg} \mathrm{m}^{-3}\right)\end{array}$ & $\begin{array}{l}\text { Average blanks } \\
\text { Particulate phase } \\
\left(\mathrm{pg} \mathrm{m}^{-3}\right)\end{array}$ \\
\hline \multirow{10}{*}{ PBDEs } & BDE28 & 0.30 & 0.2 & 1.0 & 87 & 95 & 0.2 & \\
\hline & BDE47 & 0.24 & 0.6 & 4.1 & 98 & 94 & 0.8 & $<L O Q$ \\
\hline & BDE100 & 0.66 & 0.6 & 1.6 & 102 & 86 & $<L O Q$ & $<L O Q$ \\
\hline & BDE99 & 0.51 & 0.6 & 1.6 & 107 & 88 & $<L O Q$ & $<L O Q$ \\
\hline & BDE154 & 2.04 & 1.5 & 0.8 & 92 & 89 & $<L O Q$ & $<L O Q$ \\
\hline & BDE153 & 1.41 & 1.8 & 1.0 & 100 & 94 & $<L O Q$ & $<L O Q$ \\
\hline & BDE183 & 1.35 & 1.7 & 14.9 & 103 & 89 & $<L O Q$ & $<L O Q$ \\
\hline & BDE209 & 7.5 & 9.9 & 79.1 & 98 & 93 & $<L O Q$ & $<L O Q$ \\
\hline & PeCB & 0.1 & 0.2 & 0.3 & 50 & 61 & 1.6 & 0.37 \\
\hline & $\mathrm{HCB}$ & 0.12 & 0.3 & 0.6 & 57 & 62 & 2.0 & $<L O Q$ \\
\hline \multirow{8}{*}{ Indicators } & CB28 & 0.03 & 0.9 & 0.4 & 90 & 95 & 4.1 & 2.7 \\
\hline & CB52 & 0.09 & 0.2 & 0.1 & 93 & 100 & 17.7 & 11.9 \\
\hline & CB101 & 0.1 & 1.1 & 0.2 & 96 & 101 & 8.6 & 5.2 \\
\hline & CB118 & 0.09 & 0.4 & 0.3 & 125 & 115 & 4.3 & 2.9 \\
\hline & CB138 & 0.27 & 0.4 & 0.5 & 124 & 107 & 18.0 & 22.3 \\
\hline & CB153 & 0.16 & 0.1 & 0.2 & 109 & 109 & 17.4 & 22.8 \\
\hline & CB180 & 0.11 & 0.2 & 0.4 & 133 & 109 & 3.3 & 15.2 \\
\hline & CB77 & 0.05 & 0.6 & 0.8 & 98 & 96 & $<L O Q$ & $<L O Q$ \\
\hline \multirow{3}{*}{ PCBs } & CB81 & 0.06 & 0.3 & 0.4 & 102 & 101 & $<L O Q$ & $<L O Q$ \\
\hline & CB126 & 0.18 & 0.6 & 0.3 & 127 & 112 & $<L O Q$ & $<L O Q$ \\
\hline & CB169 & 0.07 & 0.2 & 0.3 & 136 & 113 & $<L O Q$ & $<L O Q$ \\
\hline \multirow{8}{*}{ Others } & CB105 & 0.09 & 0.4 & 2.4 & 113 & 111 & 1.1 & $<L O Q$ \\
\hline & CB114 & 0.10 & 0.4 & 0.3 & 113 & 105 & $<L O Q$ & $<L O Q$ \\
\hline & CB123 & 0.10 & 0.4 & 0.3 & 125 & 103 & $<L O Q$ & $<L O Q$ \\
\hline & CB156 & 0.07 & 0.1 & 0.3 & 82 & 107 & 0.3 & 0.8 \\
\hline & CB157 & 0.06 & 0.4 & 0.3 & 134 & 108 & $<L O Q$ & $<L O Q$ \\
\hline & CB167 & 0.07 & 2.2 & 1.4 & 135 & 106 & $<L O Q$ & $<L O Q$ \\
\hline & CB189 & 0.13 & 0.2 & 0.5 & 133 & 117 & 0.2 & $<L O Q$ \\
\hline & CB110 & 0.1 & 2.1 & 0.9 & 65 & 63 & 4.9 & 3.1 \\
\hline \multirow{7}{*}{ PAEs } & DMP & 0.08 & 50.0 & 6.0 & 91 & 78 & 247 & 51 \\
\hline & DEP & 0.09 & 50 & 0.7 & 90 & 83 & 1017 & 549 \\
\hline & DiBP & 0.09 & 83 & 5.7 & 101 & 77 & 2615 & 2998 \\
\hline & DnBP & 0.06 & 69 & 9.6 & 102 & 89 & 1050 & 590 \\
\hline & $\mathrm{BBP}$ & 0.90 & 49 & 3.8 & 127 & 98 & 469 & 617 \\
\hline & DEHP & 0.30 & 92 & 2.8 & 56 & 101 & 2133 & 2092 \\
\hline & DnOP & 0.30 & 254 & 11 & 63 & 102 & $<L O Q$ & 970 \\
\hline \multirow{15}{*}{ PAHs } & Acenaphtylene & 0.27 & 46 & 1.6 & 54 & 47 & $<L O Q$ & $<L O Q$ \\
\hline & Acenaphtene & 0.12 & 9.2 & 2.1 & 67 & 50 & $<L O Q$ & $<L O Q$ \\
\hline & Fluorene & 0.09 & 137 & 0.4 & 90 & 54 & $<L O Q$ & $<L O Q$ \\
\hline & Phenanthrene & 0.18 & 2.7 & 2.1 & 76 & 55 & 193 & 16.3 \\
\hline & Anthracene & 0.19 & 6.6 & 2.1 & 67 & 55 & $<L O Q$ & $<L O Q$ \\
\hline & Fluoranthene & 1.50 & 8.1 & 0.3 & 71 & 56 & 14.7 & 11.9 \\
\hline & Pyrene & 1.58 & 1.0 & 0.3 & 61 & 55 & 11.8 & 11.6 \\
\hline & Benzo(a)anthracene & 0.63 & 1.0 & 1.8 & 53 & 53 & $<L O Q$ & 2.4 \\
\hline & Chrysène & 0.60 & 0.7 & 1.8 & 61 & 52 & $<L O Q$ & 6.8 \\
\hline & Benzo(b)fluoranthene & 0.86 & 0.7 & 0.5 & 59 & 51 & $<L O Q$ & $<L O Q$ \\
\hline & Benzo(k)fluoranthene & 0.61 & 4.6 & 0.5 & 67 & 54 & $<L O Q$ & $<L O Q$ \\
\hline & Benzo(a)pyrene & 2.50 & 4.6 & 0.4 & 60 & 46 & $<L O Q$ & $<L O Q$ \\
\hline & Indeno(1.2.3.c d)pyrene & 0.48 & 4.5 & 0.6 & 58 & 45 & $<L O Q$ & $<L O Q$ \\
\hline & Dibenzo(a.h)anthracene & 0.50 & 1.4 & 0.5 & 54 & 45 & $<L O Q$ & $<L O Q$ \\
\hline & Benzo(g.h.i)perylene & 0.27 & 2.8 & 0.5 & 87 & 95 & $<L O Q$ & 1.2 \\
\hline \multirow{2}{*}{ Phenols } & $\mathrm{BPA}$ & 4.4 & 5.4 & 18 & 120 & 22 & 300 & 196 \\
\hline & TBBPA & 0.48 & 103 & 39 & 12 & 29 & $<L O Q$ & $<L O Q$ \\
\hline
\end{tabular}

$769<L O Q:$ under limit of quantification 
770 Table SM.8: Annual compound concentrations as mean \pm SD $(n=6)$ and median for the

771 phthalates as compounds and $\sum 7$ PAEs, for the PAHs as compounds, $\sum 8$ PAHs (bold) and

$772 \sum 15 \mathrm{PAHs}$ and for the PCBs as compounds, $\sum$ PCBi (bold), $\sum$ PCB-DL (italic) and $\sum 19 \mathrm{PCBs}$.

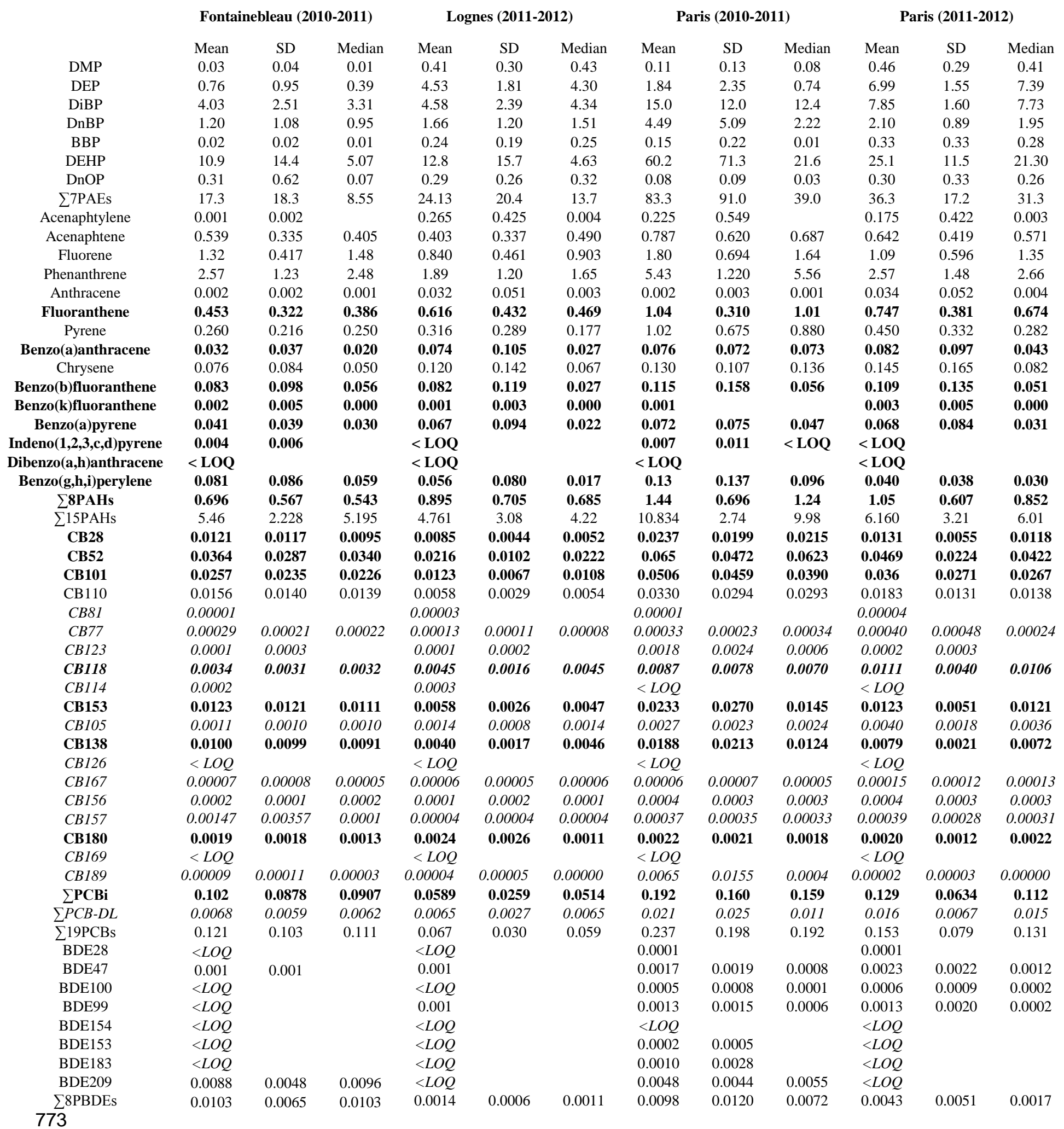


774 Table SM.9: EDC vapor pressure (Pa, at $25{ }^{\circ} \mathrm{C}$ ), $\log \mathrm{K}_{\mathrm{OA}}$ (at $25^{\circ} \mathrm{C}$ ), EDC distribution (as \%

775 of total concentration) in gaseous phase of the ambient air and $\mathrm{Kp}$, considering the mean of

776 the three sites during summer (mean temperature $20^{\circ} \mathrm{C}$ ) and winter (mean temperature 4.5

$\left.777{ }^{\circ} \mathrm{C}\right)$.

\begin{tabular}{|c|c|c|c|c|c|c|}
\hline \multirow[t]{2}{*}{ Compound } & \multirow{2}{*}{$\begin{array}{c}\text { Vapor pressure } \\
\mathrm{Pa} \text { at } 25^{\circ} \mathrm{C}\end{array}$} & \multirow{2}{*}{$\begin{array}{c}\log \mathrm{K}_{\mathrm{OA}} \\
\text { at } 25^{\circ} \mathrm{C}\end{array}$} & \multicolumn{2}{|c|}{$\%$ in gaseous phase } & \multicolumn{2}{|c|}{ Kp } \\
\hline & & & Summer & Winter & Summer & Winter \\
\hline $\mathrm{OP}$ & $6.27 \mathrm{E}-01$ & 9.24 & 88.2 & 87.1 & $1.71 \mathrm{E}-01$ & $2.10 \mathrm{E}-01$ \\
\hline NP & $6.00 \mathrm{E}-01$ & 8.62 & 88.2 & 80.6 & $1.85 \mathrm{E}-01$ & $2.43 \mathrm{E}-01$ \\
\hline CB28 & $5.81 \mathrm{E}+00$ & 8.35 & 94.5 & 95.6 & $6.01 \mathrm{E}-02$ & 7.12E-02 \\
\hline CB52 & $3.30 \mathrm{E}+00$ & 8.68 & 93.2 & 97.1 & 7.99E-02 & $3.95 \mathrm{E}-02$ \\
\hline CB101 & $5.55 \mathrm{E}-01$ & 9.45 & 93.1 & 97 & 8.39E-02 & $3.64 \mathrm{E}-02$ \\
\hline CB105 & 8.67E-04 & 9.88 & 91.8 & 91.3 & $1.03 \mathrm{E}-01$ & $1.13 \mathrm{E}-01$ \\
\hline CB110 & $9.50 \mathrm{E}-04$ & 9.45 & 90 & 93 & $9.28 \mathrm{E}-02$ & $1.02 \mathrm{E}-01$ \\
\hline CB118 & $1.75 \mathrm{E}-01$ & 9.88 & 91.5 & 94.4 & 1.02E-01 & $6.96 \mathrm{E}-02$ \\
\hline CB138 & $6.85 \mathrm{E}-02$ & 10.21 & 68 & 75.2 & $1.01 \mathrm{E}+00$ & $6.53 \mathrm{E}-01$ \\
\hline CB153 & $9.11 \mathrm{E}-02$ & 10.21 & 71 & 80 & $6.92 \mathrm{E}-01$ & $1.25 \mathrm{E}-01$ \\
\hline CB156 & $2.10 \mathrm{E}-04$ & 10.65 & 83.2 & 67.7 & $2.70 \mathrm{E}-01$ & $2.37 \mathrm{E}+00$ \\
\hline CB157 & $2.10 \mathrm{E}-04$ & 10.65 & 71.8 & 70.9 & 4.78E-01 & 2.64E-01 \\
\hline CB169 & $6.31 \mathrm{E}-05$ & 11.08 & 80.3 & 69.5 & $2.65 \mathrm{E}-01$ & 3.03E-02 \\
\hline CB180 & $1.73 \mathrm{E}-04$ & 10.98 & 81.3 & 52.2 & $2.60 \mathrm{E}-01$ & $3.30 \mathrm{E}+00$ \\
\hline CB189 & $5.01 \mathrm{E}-05$ & 11.41 & 72.9 & 12.1 & $1.12 \mathrm{E}+00$ & $1.76 \mathrm{E}+00$ \\
\hline $\mathrm{HCB}$ & $3.07 \mathrm{E}-01$ & 7.64 & 99.3 & 99.7 & $7.50 \mathrm{E}-03$ & $2.70 \mathrm{E}-03$ \\
\hline $\mathrm{PeCB}$ & $2.67 \mathrm{E}+02$ & 6.46 & 99.7 & 98.4 & $1.70 \mathrm{E}-02$ & $2.70 \mathrm{E}-03$ \\
\hline BPA & 5.33E-05 & 12.70 & 95.2 & 85 & $4.20 \mathrm{E}-02$ & $1.38 \mathrm{E}-01$ \\
\hline DMP & 2.63E-01 & 7.01 & 89.7 & 77.8 & 1.56E-01 & $3.82 \mathrm{E}-01$ \\
\hline DEP & $1.47 \mathrm{E}-01$ & 7.55 & 98.2 & 79.2 & $2.18 \mathrm{E}-02$ & $1.58 \mathrm{E}-01$ \\
\hline DnBP & 4.73E-03 & 8.56 & 98.1 & 81.7 & $1.92 \mathrm{E}-02$ & $6.99 \mathrm{E}-01$ \\
\hline DiBP & $4.73 \mathrm{E}-03$ & 8.54 & 97.4 & 90.6 & $2.82 \mathrm{E}-02$ & $1.34 \mathrm{E}-02$ \\
\hline BBP & $2.50 \mathrm{E}-05$ & 8.78 & 92.4 & 88.9 & $1.17 \mathrm{E}-01$ & $1.93 \mathrm{E}+00$ \\
\hline DEHP & $2.50 \mathrm{E}-05$ & 10.53 & 89.7 & 29 & $1.08 \mathrm{E}-01$ & $4.61 \mathrm{E}+00$ \\
\hline DnOP & $1.84 \mathrm{E}-06$ & 10.04 & 58.5 & 19.5 & 4.22E-01 & $3.11 \mathrm{E}+01$ \\
\hline BDE28 & $2.70 \mathrm{E}-04$ & 9.70 & 95.9 & 99.1 & 4.93E-02 & $5.50 \mathrm{E}-03$ \\
\hline BDE47 & $3.30 \mathrm{E}-04$ & 10.46 & 93.7 & 55.3 & 8.24E-02 & $4.88 \mathrm{E}+00$ \\
\hline BDE100 & 4.69E-05 & 11.40 & 85.5 & 51.4 & $9.17 \mathrm{E}-02$ & $1.27 \mathrm{E}+00$ \\
\hline BDE99 & 4.69E-05 & 11.20 & 50 & 34 & $1.02 \mathrm{E}+00$ & $6.38 \mathrm{E}+00$ \\
\hline BDE209 & 4.60E-06 & 15.73 & 70 & 80 & 4.62E-01 & $3.34 \mathrm{E}-01$ \\
\hline Acenaphtene & $4.14 \mathrm{E}+00$ & & 100 & 100 & & \\
\hline Fluorene & $4.50 \mathrm{E}-01$ & 7.19 & 100 & 82.9 & 4.00E-04 & $4.70 \mathrm{E}-03$ \\
\hline Phenanthrene & $5.70 \mathrm{E}-02$ & 7.90 & 99.2 & 94.8 & $5.00 \mathrm{E}-03$ & $4.20 \mathrm{E}-02$ \\
\hline Fluoranthene & $5.60 \mathrm{E}-03$ & 9.32 & 85.8 & 67.2 & $2.41 \mathrm{E}-01$ & 3.33E-01 \\
\hline Benzo(a)pyrene & $3.20 \mathrm{E}-06$ & 9.32 & 49.5 & 4.4 & 3.71E-01 & $4.47 \mathrm{E}+01$ \\
\hline Pyrene & 4.10E-03 & 9.32 & 95.5 & 75.6 & $4.85 \mathrm{E}-02$ & 4.45E-01 \\
\hline Benzo(a)anthracene & $2.30 \mathrm{E}-04$ & & 46.6 & 12.2 & 7.29E-01 & $1.53 \mathrm{E}+01$ \\
\hline Chrysene & $4.80 \mathrm{E}-05$ & & 50.6 & 25.4 & $5.97 \mathrm{E}-01$ & $1.16 \mathrm{E}+01$ \\
\hline Benzo(g,h,i)perylene & $1.10 \mathrm{E}-12$ & & 27.1 & 3.6 & 2.62E-01 & $5.66 \mathrm{E}+01$ \\
\hline
\end{tabular}

